\title{
Differential Modulation of the Oligodendrocyte Transcriptome by Sonic Hedgehog and Bone Morphogenetic Protein 4 via Opposing Effects on Histone Acetylation
}

\author{
Muzhou Wu, ${ }^{1,3}$ Marylens Hernandez, ${ }^{1,3}$ Siming Shen, ${ }^{1,3,4}$ Jennifer K. Sabo, ${ }^{5}$ Dipti Kelkar, ${ }^{1,3}$ Ju Wang ${ }^{1,3}$ Robert 0 'Leary, ${ }^{1,3}$ \\ Greg R. Phillips, ${ }^{1,3}$ Holly S. Cate, ${ }^{5}$ and Patrizia Casaccia ${ }^{1,2,3}$ \\ Departments of ${ }^{1}$ Neuroscience, ${ }^{2}$ Genetics and Genomic Sciences, and ${ }^{3}$ Center of Excellence on Myelin Disorders, Friedman Brain Institute, Mount Sinai \\ School of Medicine, New York, New York 10029, ${ }^{4}$ Graduate Program in Neuroscience, Robert Wood Johnson Medical School, University of Medicine and \\ Dentistry of New Jersey, Piscataway, New Jersey 08854, and ${ }^{5}$ Florey Neuroscience Institutes and Centre for Neuroscience, University of Melbourne, \\ Parkville, Victoria 3010, Australia
}

Differentiation of oligodendrocyte progenitor cells (OPCs) into mature oligodendrocytes is regulated by the interplay between extrinsic signals and intrinsic epigenetic determinants. In this study, we analyze the effect that the extracellular ligands sonic hedgehog (Shh) and bone morphogenetic protein 4 (BMP4), have on histone acetylation and gene expression in cultured OPCs. Shh treatment favored the progression toward oligodendrocytes by decreasing histone acetylation and inducing peripheral chromatin condensation. BMP4 treatment, in contrast, inhibited the progression toward oligodendrocytes and favored astrogliogenesis by favoring global histone acetylation and retaining euchromatin. Pharmacological treatment or silencing of histone deacetylase 1 (Hdac1) or histone deacetylase 2 (Hdac2) in OPCs did not affect BMP4-dependent astrogliogenesis, while it prevented Shh-induced oligodendrocyte differentiation and favored the expression of astrocytic genes. Transcriptional profiling of treated OPCs, revealed that BMP4-inhibition of oligodendrocyte differentiation was accompanied by increased levels of Wnt (Tbx3) and Notch-target genes (Jag1, Hes1, Hes5, Hey1, and Hey2), decreased recruitment of Hdac and increased histone acetylation at these loci. Similar upregulation of Notch-target genes and increased histone acetylation were observed in the corpus callosum of mice infused with BMP4 during cuprizone-induced demyelination. We conclude that Shh and Bmp4 differentially regulate histone acetylation and chromatin structure in OPCs and that BMP4 acts as a potent inducer of gene expression, including Notch and Wnt target genes, thereby enhancing the crosstalk among signaling pathways that are known to inhibit myelination and repair.

\section{Introduction}

Oligodendrocytes are the myelin-forming cells of the CNS. Their differentiation from oligodendrocyte progenitor cells (OPCs) results from transcriptional changes in gene expression and is favored by sonic hedgehog (Shh; Orentas et al., 1999; Nery et al., 2001), thyroid hormone (Barres et al., 1994; Orentas et al., 1999; Pombo et al., 1999; Nery et al., 2001), IGF1 (Mason et al., 2000; Back et al., 2007) and retinoic acid (Huang et al., 2011) and antagonized by mitogenic stimuli such as PDGF and FGF (Barres et al., 1994; Baron et al., 2000; Fortin et al., 2005; Zhou and Armstrong, 2007), Wnt (Fancy et al., 2009; Feigenson et al., 2011), Notch (Wang et al., 1998; Zhang et al., 2009, 2010) and

Received Sept. 24, 2011; revised Feb. 25, 2012; accepted March 21, 2012.

Author contributions: P.C. designed research; M.W., M.H., S.S., J.K.S., D.K., J.W., and R.O. performed research; M.W., M.H., J.K.S., G.R.P., H.S.C., and P.C. analyzed data; M.W., H.S.C., and P.C. wrote the paper.

This study was supported by Grant NIH-R01-NS 42925-10 to P.C. and by a Minority Fellowship Supplement to M.H. (NIH-R01-NS 42925-08S2). J.K.S. is supported by a Multiple Sclerosis Research Australia Postgraduate Scholarship, and H.S.C. is supported by the National Health and Medical Research Council of Australia.

The authors declare no competing financial interests.

Correspondence should be addressed to Patrizia Casaccia, Mount Sinai School of Medicine, One Gustave Levy Place, Box 1065, New York, NY 10029. E-mail: patrizia.casaccia@mssm.edu.

DOI:10.1523/JNEUROSCI.4876-11.2012

Copyright $\odot 2012$ the authors $\quad 0270-6474 / 12 / 326651-14 \$ 15.00 / 0$
BMP4 (Grinspan et al., 2000; Gomes et al., 2003; See et al., 2004; Sim et al., 2006). The progression from OPCs to mature oligodendrocytes occurs in stages and is characterized by complex cytoskeletal (Liu et al., 2003) and transcriptional changes (Dugas et al., 2006; Cahoy et al., 2008; Swiss et al., 2011) and progressive chromatin compaction (Mori and Leblond, 1970; Peters and Sethares, 2004; Menn et al., 2006). We and others (MarinHusstege et al., 2002; Shen et al., 2005, 2008; Liu et al., 2006, 2010; Ye et al., 2009) have previously reported that changes of acetylation levels in nucleosomal histones, the basic unit of chromatin, are critical for oligodendrocyte differentiation in the developing brain and in repair after demyelination in adult mice. However it is not clear whether extracellular signals with antagonistic roles in oligodendrocyte differentiation, also differentially regulate histone acetylation. In this study we asked whether two extracellular signals that either favor (i.e., Shh) or inhibit (i.e., BMP4) OPC differentiation into oligodendrocytes, modulate changes in gene expression by differential effects on histone acetylation.

Shh belongs to the hedgehog family of factors, which promotes oligodendrogliogenesis (Orentas et al., 1999; Nery et al., 2001; Soula et al., 2001; Tekki-Kessaris et al., 2001), while BMP4 is a member of the TGF $\beta$ super family of ligands which promotes 
astroglial lineage determination (Gross et al., 1996) at the expense of oligodendrogliogenesis (Wada et al., 2000; Miller et al., 2004; Samanta and Kessler, 2004) and prevents differentiation of OPC (Grinspan et al., 2000; See et al., 2004). More recently, several studies have suggested that BMP4 also affects neurogenesis and gliogenesis in the adult brain (Colak et al., 2008; Jablonska et al., 2010) and modulates repair after demyelination (Cate et al., 2010; Sabo et al., 2011). Therefore, we also asked whether in vivo BMP4 would induce similar changes to those detected in vitro, in cultured oligodendrocytes and affect histone acetylation and gene expression.

\section{Materials and Methods}

Antibodies and reagents. Acetyl- Histone 3 (06-599, Millipore); Histone 3 (ab1791, Abcam); Histone H3K9Ac (ab4441, Abcam); A2B5, O4 and O1 antibodies (conditioned medium from hybridoma cells provided by Dr. R. Bansal, University of Connecticut, Farmington, CT); HDAC1 (PA1-186, ABR); HDAC2 (ab7029 Abcam); HDAC2 (SC-7899, Santa Cruz Biotechnology); HDAC3 (SC-11417, Santa Cruz Biotechnology); HDAC8 (SC11405, Santa Cruz Biotechnology); GFAP (Z0334, Dako); GFAP (AVES Laboratories INC.); Caspase-3 (AB3623, Millipore); Shh (461-SH, R\&D Systems); BMP4 (314-BP, R\&D Systems); Noggin (719-NG, R\&D Systems); valproic acid (VPA) (P4543, Sigma); XAV 939 (3748, Tocris Bioscience); iCRT 14 (4299, Tocris Bioscience), SAHM1(491002, EMD Chemicals).

Cell culture. Oligodendrocyte progenitors were isolated from the cortex of postnatal day 1 rats, and cultured according to McCarthy and de Vellis (1980). After shaking from the flasks, progenitors were immunoselected using A2B5 antibodies and secondary antibodies conjugated with magnetic beads (Miltenyi Biotech). OPCs were maintained proliferating in the presence of bFGF $(20 \mathrm{ng} / \mathrm{ml})$ and PDGF $(10 \mathrm{ng} / \mathrm{ml})$, while oligodendrocyte differentiation was induced by culturing the cells in the absence of mitogens. Treatment with VPA ( $1 \mathrm{~mm})$, Shh $(1 \mu \mathrm{g} / \mathrm{ml})$, BMP4 $(50 \mathrm{ng} / \mathrm{ml})$ or Noggin $(1 \mu \mathrm{g} / \mathrm{ml})$ was initiated when the culture medium was replaced with mitogen-free medium.

Time-lapse video microscopy. For the time-lapse imaging of Shh or BMP4-induced OPC differentiation, primary oligodendrocyte progenitors were plated at a density of $2 \times 10^{4}$ into 8 -well cover glass bottom slides (Nunc) and treated with either Shh $(1 \mu \mathrm{g} / \mathrm{ml})$ or BMP4 (50 ng/ml). Live cell images were captured every $5 \mathrm{~min}$ for the first $4 \mathrm{~h}$ of treatment, using the AxioObserver $\mathrm{Z} 1$ inverted fluorescence microscope equipped with controlled humidity, temperature and $\mathrm{CO}_{2}$ incubation system (Carl Zeiss MicroImaging). Cells were then allowed to re-equilibrate $\mathrm{pH}$ and $\mathrm{CO}_{2}$ levels in the incubator for $23 \mathrm{~h}$ and the following day, additional live cell images were captured every $5 \mathrm{~min}$ for an additional $4 \mathrm{~h}$.

HDAC activity assay. HDAC activity was measured by HDAC Activity Assay/Drug Discovery Kit (BIOMOL Research Laboratories). Experimental procedures were designed and performed according to the protocol provided (BIOMOL Research Laboratories). Lysates from cultured cells were used as sources for HDAC activity. Sample lysates containing $20 \mu \mathrm{g}$ of protein were added to a 96-well plate in $25 \mu \mathrm{l}$ HDAC assay buffer (BIOMOL Research Laboratories). A fluorimetric acetylated substrate was added and the reaction was allowed to proceed at room temperature for $1 \mathrm{~h}$, followed by an incubation with developer for 10-15 min. Enzymatic activity was measured using a microtiter plate-reading fluorimeter (excitation at $360 \mathrm{~nm}$, detection of emitted light at $460 \mathrm{~nm}$ ).

Immunocytochemistry. Cells were grown on CC2-coated 8 well chambers (Lab-Tek) for all immunocytochemistry. For staining oligodendrocyte lineage markers, cells were rinsed gently with PBS and incubated live with $\mathrm{A} 2 \mathrm{~B} 5, \mathrm{O} 4$, or $\mathrm{O} 1$ hybridoma supernatant $(1: 10)$ for $30 \mathrm{~min}$ at $37^{\circ} \mathrm{C}$. Cells were then fixed with $1 \%$ paraformaldehyde for $20 \mathrm{~min}$ at room temperature and first incubated with pageing solution (PGBA plus $10 \%$ normal goat serum) for 30 min followed by incubation with secondary antibodies for $1 \mathrm{~h}$ at room temperature. For costaining with antibodies against AcH3, GFAP, class I HDACs, cells were equilibrated with Triton $\mathrm{X}-100$ containing pageing solution (PGBA plus $10 \%$ normal goat serum, and $0.5 \% \mathrm{TX}-100$ ) for $30 \mathrm{~min}$, then processed for additional primary antibody staining followed by the appropriate secondary antibody. Cells were then counterstained with $4^{\prime}, 6^{\prime}$-diamidino-2-phenylindole (DAPI; 1:5000; Invitrogen) to visualize cell nuclei. Labeled cells were counted in at least three fields, from two or three separate cultures performed in duplicate, using a confocal microscope (LSM710, Zeiss). The intensity of $\mathrm{AcH} 3$ fluorescence staining was measured in arbitrary units using NIH ImageJ software.

Induction of demyelination. Cuprizone-mediated demyelination was induced by feeding 8 -week-old female C57BL/6 mice powdered feed (Barastoc) containing $0.2 \%$ cuprizone (w/w: bis-cyclohexanone-oxaldihydrazone; Sigma-Aldrich; Alfa Aesar) daily as previously described (Sabo et al., 2011).

Immunohistochemistry. Mice were anesthetized and perfused intracardially with PBS followed by $4 \%$ paraformaldehyde. Brains were postfixed for $30 \mathrm{~min}$ at $4^{\circ} \mathrm{C}$ and then equilibrated in $20 \%$ sucrose in PBS overnight at $4^{\circ} \mathrm{C}$ for cryoprotection before being embedded in Tissue-Tek O.C.T. (Sakura), frozen using isopentane (Ajax Finechem) on dry ice, and stored at $-80^{\circ} \mathrm{C}$. For fluorescence microscopy, $10 \mu \mathrm{m}$ coronal cryostat sections were probed with platelet-derived growth factor $\alpha$ receptor (PDGRA; rat; eBioscience; 1:500) and Acetyl-Histone $\mathrm{H} 3$ (AcH3; rabbit; Millipore; 1:200) overnight at room temperature followed by incubation with secondary antibodies for $1 \mathrm{~h}$. The secondary antibody incubation included Hoescht 33342 (1:10,000; Invitrogen) to visualize the nucleus of all cells. BrdU detection was described previously (Cate et al., 2010). Cell counts were performed blind to experimental treatment. Immunopositive cells were quantified as previously described (Cate et al., 2010). Images were taken from 3 sections $50 \mu \mathrm{m}$ apart for each animal at locations between bregma $-1.58 \mathrm{~mm}$ and $-1.82 \mathrm{~mm}$ as previously described.

Intraventricular infusion. Acute demyelination was induced after 4-weeks of cuprizone ingestion and then mice received recombinant BMP4 (R\&D Systems) dissolved in artificial CSF (aCSF) at a dose of 400 $\mathrm{ng} / \mathrm{d}$ or aCSF delivered by ALZET osmotic pumps (Model 1007) at a flow rate of $0.50 \mathrm{ml} / \mathrm{h}$ for 5 days during cuprizone challenge. The ALZET Brain Infusion Kit III was used with the osmotic pumps to infuse via a cannula, which was implanted at coordinates previously described (Sabo et al., 2011). Mice undergoing surgery for cannula and osmotic pump implantation were monitored as previously described (Cate et al., 2010). Mice received $1 \mathrm{mg} / \mathrm{ml} \mathrm{BrdU}$ in their drinking water for the final 3 days of the infusion.

In situ hybridization. DIG labeled in situ riboprobes were generated by in vitro transcription from a $\sim 1.1 \mathrm{~kb}$ cDNA clone (Open Biosystems). In situ hybridizations were performed on $10 \mu \mathrm{m}$ cryostat sections with Heyl probe according to standard protocols. Fluorescent in situ hybridization was performed with Fast Red (Roche) and followed by AcetylHistone $\mathrm{H} 3$ immunohistochemistry. The secondary antibody incubation included Hoescht 33342 (1:10,000; Invitrogen) to visualize the nucleus of all cells.

Electron microscopy for evaluation of nuclear condensation. After 4 days of treatment, cells were fixed for $30 \mathrm{~min}$ with $4 \%$ glutaraldehyde in $0.1 \mathrm{M}$ sodium cacodylate buffer with $1 \mathrm{mM} \mathrm{CaCl}_{2}$. The location of the cell on the coverslip grid was determined using brightfield illumination. The cells were then processed for transmission electron microscopy, washed and treated with $1 \%$ osmium tetroxide, $1.5 \%$ potassium ferracyanide in $0.1 \mathrm{M}$ cacodylate buffer for $1 \mathrm{~h}$ at $4^{\circ} \mathrm{C}$. After dehydration, cells were kept in $3 \%$ uranyl acetate in $70 \%$ ethanol for $12 \mathrm{~h}$ at $4^{\circ} \mathrm{C}$, further dehydrated and then embedded (Embed 812 kit; Electron Microscopy Sciences) and sectioned. Sections were contrasted with lead citrate and uranyl acetate, and serial sections of the nucleus for the cell of interest were documented at magnifications of $\times 12,000$ and $\times 50,000$.

Lentiviral shRNA infection. Hdac1, Hdac2, Hdac3 and Hdac8 Lentiviral shRNA Transduction Particles were purchased from Sigma-Aldrich.

The sequences of the shRNAs targeting the following mouse genes are

Hdacl: TRCN0000039401: CCGGCCCTACAATGACTACTTTGAAC TCGAGTTCAAAGTAGTCATTGTAGGGTTTTTG

Hdac2: TRCN0000039396: CCGGGCTGTGAAATTAAACCGGCAAC TCGAGTTGCCGGTTTAATTTCACAGCTTTTTG

Hdac3: TRCN0000039389: CCGGCGTGGCTCTCTGAAACCTTAAC

TCGAGTTAAGGTTTCAGAGAGCCACGTTTTTG

Hdac8: TRCN0000088000: CCGGGCAGATACTATTGCCGGAGATC TCGAGATCTCCGGCAATAGTATCTGCTTTTTG 
Table 1. Primers used for quantitative real-time $P C R$ in rat $O P C$

\begin{tabular}{|c|c|c|}
\hline Gene & Forward & Reverse \\
\hline Hey1 & 5'-AGTGAGCTGGACGAGACCAT-3' & 5'-CTGGGTACCAGCCTTCTCAG-3' \\
\hline Hey2 & 5' -GATCTGCCA AGTTGGAAAAGG-3' & 5'-TGTTGCCTGGAGCATCTTC-3' \\
\hline Hes1 & $5^{\prime}$-CAGAAAGTCATCAAAGCCTATCATG-3' & 5'-TCAGTGTTTTCAGTTGGCTCAAA-3' \\
\hline Hes5 & 5'-ATGCGTCGGGACCGCATCAAC-3' & 5'-GGCGAAGGCTTTGCTGTGCTTC-3' \\
\hline Notch1 & 5'-GCACCTGCATTGATGATGTC-3' & 5'-CTCCTTGCATACCCCACTGT-3' \\
\hline Jag1 & $5^{\prime}$-CCACTCGCGTGACAGCCAGT-3' & $5^{\prime}-C C C A G C C A C C A G G A C A C A T G C-3^{\prime}$ \\
\hline$T b \times 3$ & 5'-TGGATGTCCAAAGTCGTCAC-3' & 5'-TCAGAATGTCGTTGGCTCTG-3' \\
\hline Id4 & 5' -GGTTACGTTGTGACAAGCGAACT-3' & 5'-TAAAACAACGTCGCCAATGC-3' \\
\hline Id 2 & $5^{\prime}$-CTCCAAGCTCAAGGAACTGG-3' & 5'-GTGCTGCAGGATTTCCATCT-3' \\
\hline Gapdh & 5'-AGACAGCCGCATCTTCTTGT-3' & 5'-CTTGCCGTGGGTAGAGTCAT-3' \\
\hline $18 \mathrm{~s}$ & 5'-AGTCCCTGCCCTTTGTACACA-3' & $5^{\prime}$-GATCCGAGGGCCTCACTAAAC-3' \\
\hline
\end{tabular}

Table 2. Primers used for quantitative real-time PCR in OliNeu cells

\begin{tabular}{lll}
\hline Gene & Forward & Reverse \\
\hline Gapdh & 5'-ACCCAGAAGACTGTGGATGG-3' & 5'-CACATTGGGGGTAGGAACAC-3' \\
Hey1 & 5'-AGCAGTGAGGTGAAGGGAGA-3' & 5'-AACGGGAAATCCGTGAGAC-3' \\
Hey2 & 5'-CAGGGGTAAAGGCTACTTTG-3' & 5'-AGCACTCTCGGATCCAATG-3' \\
Hes5 & 5'-ATGCTCAGTCCCAAGGAGAA-3' & 5'-GGTAGCTGACGGCCATCTC-3' \\
Tbx3 & 5'-CAGCTCACACTGCAGTCCAT-3' & 5'-GTGCTCCTCCTTGCTCTCAG-3' \\
\hline
\end{tabular}

ShRNA infection in primary OPCs was performed in cell suspension following harvesting. M.O.I 5 was used for the infection. Polybrene was added at a final concentration of $4 \mu \mathrm{g} / \mathrm{ml}$ to increase the infection efficiency. The virus/cell mixture was incubated in $37^{\circ} \mathrm{C}$ for $2 \mathrm{~h}$, and plated at desired density. The next day, cells were changed to complete growth medium (PDGF, FGF) for $24 \mathrm{~h}$, followed by subsequent experimental treatments.

Quantitative real time-PCR. RNA was isolated following manufacturer's instruction and cleaned using RNeasy Mini kit (Qiagen; Transcripts were amplified from samples derived from primary rat OPC, using the primers listed in Table 1 and from mouse OliNeu cells, using the primers listed in Table 2).

Chromatin immunoprecipitation assay. Olineu cells $\left(10 \times 10^{6}\right)$ treated with Shh or BMP4 were crosslinked in 1\% formaldehyde for $10 \mathrm{~min}$ and lysed in cell lysis buffer [HEPES $5 \mathrm{~mm}, \mathrm{KCl} 85 \mathrm{~mm}$, NP40 0.5\%, protease inhibitor cocktail $1 \times(\mathrm{p} 8340$, Sigma), phosphatase inhibitor cocktail $1 \times$ (Sigma catalog \#p0044), TSA $30 \mathrm{~nm}$ (Sigma catalog \#T8552)] on ice for 15 min. The nuclei, were lysed in buffer containing Tris- $\mathrm{HCl} 50 \mathrm{~mm}, \mathrm{pH} 8$, EDTA $10 \mathrm{~mm}$, SDS 1\% and chromatin was fragmented using the Bioruptor (Diagenode) sonicator to produce an average size of 250-300 base pairs. Chromatin concentration was measured by its absorbance at $260 \mathrm{~nm}$ in the Nanodrop $(1 \mathrm{U} / \mathrm{ml}$ of chromatin corresponds to OD260 = 1) and diluted $1: 10$ with dilution buffer $(\mathrm{NaCl} 165 \mathrm{~mm}$, SDS $0.01 \%$, Triton X-100 1.1\%, EDTA $1.2 \mathrm{~mm}$, Tris-HCl $16.7 \mathrm{~mm}, \mathrm{pH} 8.0)$. One unit of chromatin was immunoprecipitated by protein A magnetic beads (Dynabeads-Invitrogen 100.01D) after incubation with antibodies specific for histone H3-Ac (Millipore 06-5999), histone H3K9Ac (Abcam ab4441), HDAC1 (Thermo Scientific PA1869), HDAC2 (Abcam ab7029). A nonantibody sample was used as negative control. Following overnight immunoprecipitation, beads were washed twice consecutively with the following buffers: Lio-B (HEPES 50 $\mathrm{mm}, \mathrm{pH}$ 8.0, $\mathrm{NaCl} 140 \mathrm{~mm}$, Triton X-100 1\%, Sodium deoxycholate $0.1 \%$, EDTA 1 mm), Hio-B (HEPES 50 mm, pH 8.0, NaCl 500 mm, Triton X-100 $1 \%$, Sodium deoxycholate $0.1 \%$, EDTA $1 \mathrm{~mm}$ ), $\mathrm{LiCl}$ (Tris- $\mathrm{HCl} 10 \mathrm{~mm}, \mathrm{LiCl}$ $250 \mathrm{~mm}, \mathrm{NP}-40$ 0.5\%, Sodium deoxycholate $0.5 \%$, EDTA $1 \mathrm{~mm}$ ) and TE (Tris-HCl $10 \mathrm{~mm}, \mathrm{pH}$ 8.0, EDTA $1 \mathrm{~mm}$ ). Immunoprecipitated chromatin and input DNA were reverse crosslinked in elution buffer (Tris- $\mathrm{HCl} 50 \mathrm{~mm}$, EDTA $10 \mathrm{~mm}$, SDS $1 \%)$ in the presence of proteinase $\mathrm{K}(50 \mu \mathrm{g} / \mathrm{ml})$ by shaking (1300 RPM) at $68^{\circ} \mathrm{C}$ using a thermomixer (Eppendorf) for $2 \mathrm{~h}$. DNA was purified using phenol-chloroform and precipitated overnight in ethanol at $-20^{\circ} \mathrm{C}$. DNA pellets were dissolved in $200 \mu \mathrm{l}$ of ddH2O and amplified by quantitative PCR, using primers specific for selected genomic regions, as indicated in Table 3.

Microarray data analysis. RNA samples were extracted from cultured cortical rat OPCs treated for $24 \mathrm{~h}$ with either Shh $(1 \mu \mathrm{g} / \mathrm{ml})$, BMP4 (50
Table 3. Primers used in quantitative ChIP

\begin{tabular}{|c|c|c|}
\hline Gene & Forward & Reverse \\
\hline Hey1 (P1) & 5'-AGCGTGAGTGGGATCAGTGT-3' & 5'-GGGTGAGCTCTCTTCATGGT-3' \\
\hline Hey1 (P2) & 5'-CTGCAGTTAACTCCTCCTTGC-3' & 5'-TTTTCCACCTCGATGGTCTC-3' \\
\hline Hey1 (P3) & $5^{\prime}$-CATGAAGAGAGCTCACCCAGA-3' & 5'-GCCAACTCACCCATTCTCGT-3' \\
\hline Hey2 (P1) & 5'-GTTCCGCTAGGCGACAGTAG-3' & 5'-GTTCCGCTAGGCGACAGTAG-3' \\
\hline Hey2 (P2) & 5'-GTTCCGCTAGGCGACAGTAG-3' & 5'-GCTCACCCAGGGTAATTGTT-3' \\
\hline$T b \times 3(P 1)$ & $5^{\prime}$-CGCAGGAGCTAGAGGATCTG-3' & $5^{\prime}$-CGAGCGCTACAGTTCAAGC-3' \\
\hline$T b \times 3(P 2)$ & 5'-TCGCTCGCTCTCTTTCTCTC-3' & 5'-GGCTGTCTTCCTTGTGCTAAA-3' \\
\hline
\end{tabular}

$\mathrm{ng} / \mathrm{ml})$ or with Shh $(1 \mu \mathrm{g} / \mathrm{ml})+$ VPA $(1 \mathrm{~mm})$ and the isolated RNA was hybridized to the Rat Affymetrix 230.2 Gene Chip, containing 31,100 probe sets. Affymetrix CEL files were processed with Affy and Limma packages from the Bioconductor project in R (Gautier et al., 2004; Gentleman et al., 2004; Smyth, 2004). The MAS5 algorithm from Affy was used for data normalization and background correction. The statistical assessment of differentially expressed genes was performed using Limma. A false discovery rate (FDR) of $5 \%$ was chosen as statistical significance to define the genes that were differentially expressed.

Gene ontology analysis. The gene ontology analysis was performed using DAVID database (Database for Annotation, Visualization and Integrated Discovery; Dennis et al., 2003; Huang da et al., 2009b). The final gene list, obtained from the intersection of genes upregulated by BMP4 and Shh +VPA, but not upregulated by Shh, was analyzed for enrichment of gene ontology terms found in the "biological process" library. Only those ontology terms with a significant $p$ value of enrichment $(<0.05)$ were considered for this analysis.

Transcription factor binding sites. The software MatInspector from Genomatix (Genomatix Software) was used to search the binding sites for SMAD, Gli Homeodomain- and basic-helix-loop-helix family of transcription factors on the promoter regions of selected genes.

Statistical methods. The statistical significance between two groups was determined by Student's $t$ test. Data were expressed as mean \pm SEM. The statistical significance is either described in figure legends, or indicated as asterisks $\left.{ }^{*}\right)$. A $p$ value of $<0.05$ was considered to be statistically significant $\left({ }^{\star} p<0.05,{ }^{* *} p<0.01,{ }^{* *} p<0.001\right)$.

\section{Results}

The opposing effects of Shh and BMP4 on the decision of OPC to differentiate along the oligodendrocytic or astrocytic lineage are associated with differences in nuclear chromatin Our experimental system consisted of a homogeneous population of A2B5+ oligodendrocyte progenitors isolated from neonatal rat cortex by immunoselection using antibodies conjugated to magnetic beads. The relative proportion of A2B5-immunoreactive cells in this experimental system was $>97.8 \%$, with $0.47 \%$ being GFAP+ astrocytes and $0.01 \%$ microglial cells (Fig. $1 A, B$ ). These cells were cultured in the presence of either Shh or BMP4 for 5 days and then analyzed by immunocytochemistry using antibodies specific for the lineage markers $\mathrm{O} 4$ and $\mathrm{O} 1$ (to test progression into oligodendrocytes) and for GFAP (to test differentiation into astrocytes). In agreement with previous reports, Shh treatment for 5 days favored the generation of $\mathrm{O}_{4}^{+}$late oligodendrocytes progenitor and $\mathrm{O}^{+}{ }^{+}$mature oligodendrocytes compared with chemically defined mitogenfree medium. BMP4, in contrast, induced the generation of GFAP ${ }^{+}$ astrocytes at the expenses of oligodendrocytes (Fig. 1C,D). Cotreatment with BMP4 and its receptor antagonist Noggin, attenuated the extent of astrocytic differentiation and promoted the generation of $\mathrm{O}_{4}{ }^{+}$and $\mathrm{O}_{1}{ }^{+}$mature oligodendrocytes (Fig. 1C,D). Interestingly, cotreatment with BMP4 and Shh prevented differentiation of progenitors into either lineage and retained the majority of the cells as undifferentiated and characterized by the expression of A2B5 (Fig. $1 E, F)$.

To ascertain whether the effects of BMP4 and Shh were due to modulation of differentiation rather than a nonspecific effect on 
A A2B5/GFAP/IBA1/DAPI
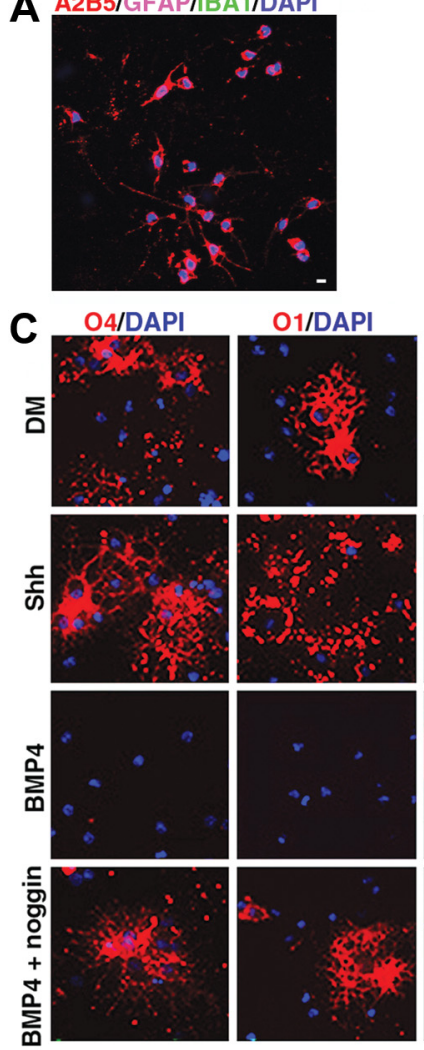

E A2B5/DAPI

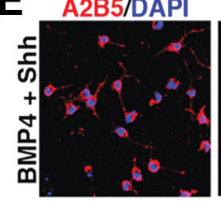

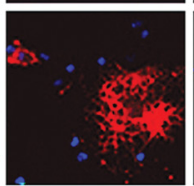

O4/DAPI

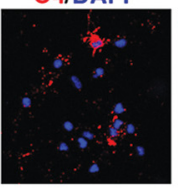

B
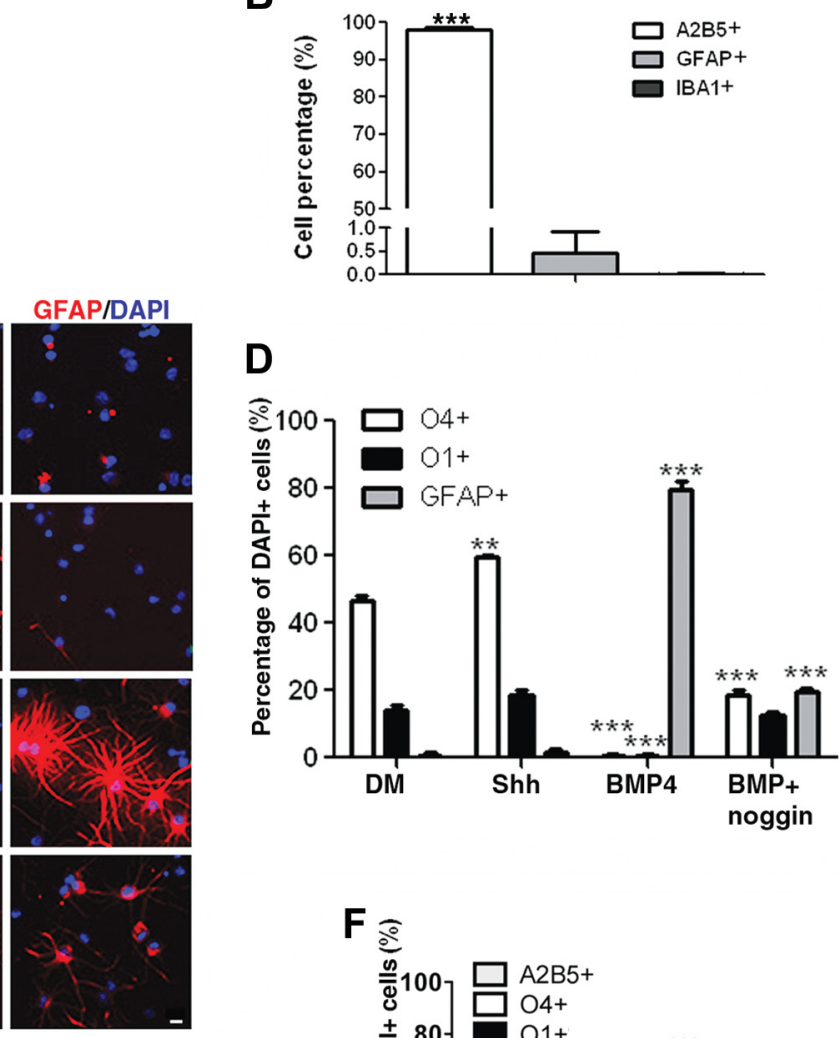

01/DAPI
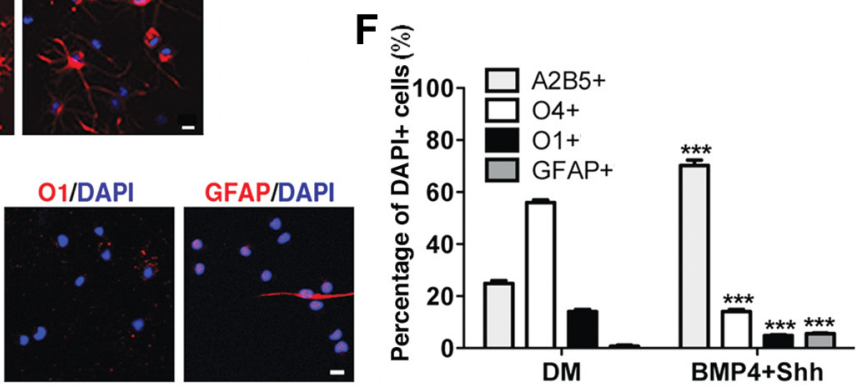

Figure 1. Shh and BMP4 play opposing roles in oligodendrocyte differentiation. $A$, Rat primary OPCs were immunoselected using magnetic beads and an antibody specific for the progenitor marker A2B5. B, The composition of the OPC culture was examined by immunostaining and counting the number of $\mathrm{AZBS}^{+} \mathrm{OPCS}, \mathrm{GFAP}^{+}$astrocytes and IBA1 ${ }^{+}$microglial cells $(* * * p<0.001)$. $C$, Immunocytochemistry of OPCs cultured for 5 days in chemically defined medium alone (DM), or with sonic hedgehog (Shh $1 \mu \mathrm{g} / \mathrm{ml})$, bone morphogenic protein 4 (BMP4 $50 \mathrm{ng} / \mathrm{ml})$, or with BMP4 and its antagonist Noggin (BMP450 $\mathrm{ng} / \mathrm{ml}+$ Noggin $1 \mu \mathrm{g} / \mathrm{ml}$ ) and stained with the 04 antibody to identify late progenitors, 01 to label galactocerebroside on mature oligodendrocytes and GFAP to label astrocytes. $D$, Bar graph represent the percentage of $04^{+}, 01^{+}$or GFAP ${ }^{+}$cells relative to total DAPI ${ }^{+}$nuclei. $\boldsymbol{E}$, Immunocytochemistry of OPC cultures maintained for 5 days in medium containing both Shh ( $1 \mu \mathrm{g} / \mathrm{ml}$ ) and BMP4 $(50 \mathrm{ng} / \mathrm{ml}) . \boldsymbol{F}$, Bar graphs indicate the percentage of $\mathrm{A2BS}^{+}, 04^{+}, 01^{+}$or $\mathrm{GFAP}^{+}$cells relative to the total number of DAPI ${ }^{+}$nuclei. Scale bars: $\mathrm{A}, 10 \mu \mathrm{m} ; \boldsymbol{C}, \boldsymbol{E}, 20 \mu \mathrm{m}$.

cell survival, we treated cells with either BMP4 or Shh for 1,2, or 3 days and assessed the presence of apoptotic cells by colabeling with lineage markers (Fig. 2A). No difference was observed between the two treatment groups. We also assessed the total number of cells during the same time period and revealed that it was not statistically significantly different in the distinct treatment groups (Fig. $2 \mathrm{~B}$ ), thereby ruling out the possibility that the differences in number of mature oligodendrocytes and astrocytes observed after treatment with Shh or BMP4 could be consequent to selective death or amplification of specific subpopulations of cells. To further confirm that Shh and BMP4 act on the same cell types and modulate lineage choices we also performed live imaging of cultured OPCs during the first $32 \mathrm{~h}$ of treatment with BMP4 or Shh (Fig. 2C). On the first day of treatment, OPC cultures were homogeneous and characterized by cells with the typical bipolar morphology. No major morphological changes were detected during the first $4 \mathrm{~h}$ of treatment. Twenty four hours later, however, it was possible to distinguish between the BMP4treated cells, characterized by few thick cytoplasmic expansions and a slight enlargement and flattening of the cell body and the Shh-treated cells, characterized by multiple thin processes and rounding-up of the soma (Fig. 2C). Together with the cell counts, the live imaging data supported the conclusion that the effect of Shh or BMP4 treatment on OPC was on lineage progression, rather than survival.

In addition to the morphological changes and the induction of cell-specific markers, Shh and BMP4 had distinct effects on nuclear chromatin. While Shh-treated cells were characterized by electron-dense chromatin aggregates distributed along the nuclear periphery, BMP4-treated cells retained a dispersed and homogeneously distributed euchromatin (Fig. 2D). Thus, the differential effect of Shh or BMP4 treatment on OPCs was associated with clear differences in nuclear chromatin.

Opposing effects of Shh and BMP4 on histone acetylation and nuclear chromatin conformation in cultured progenitors

It is well established that changes in nuclear chromatin are consequent to post-translational modifications of nucleosomal histones and therefore we asked whether Shh and BMP4 differentially modulated histone acetylation. Confocal analysis of cells stained with acetyl-H3 revealed strong immunoreactivity in BMP4-treated cells, weak immunoreactivity in OPCs treated 
A A2B5/O4/GFAPICaspase3/DAPI
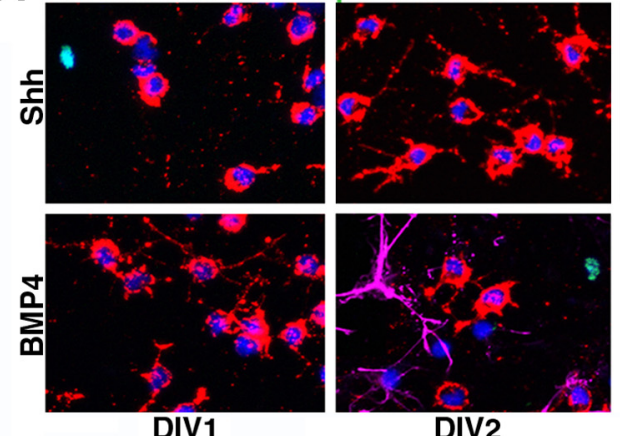

DIV2

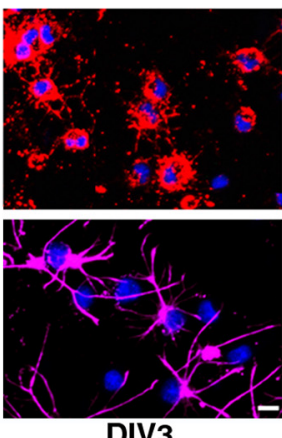

\section{B}

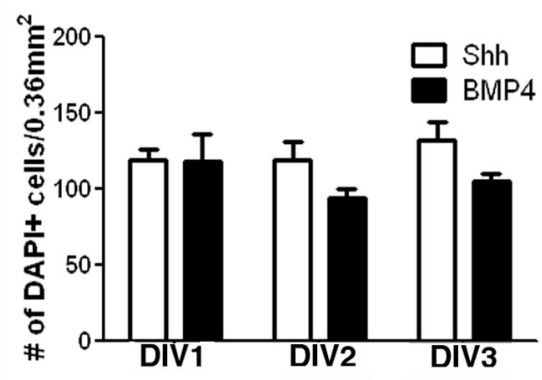

C Shh
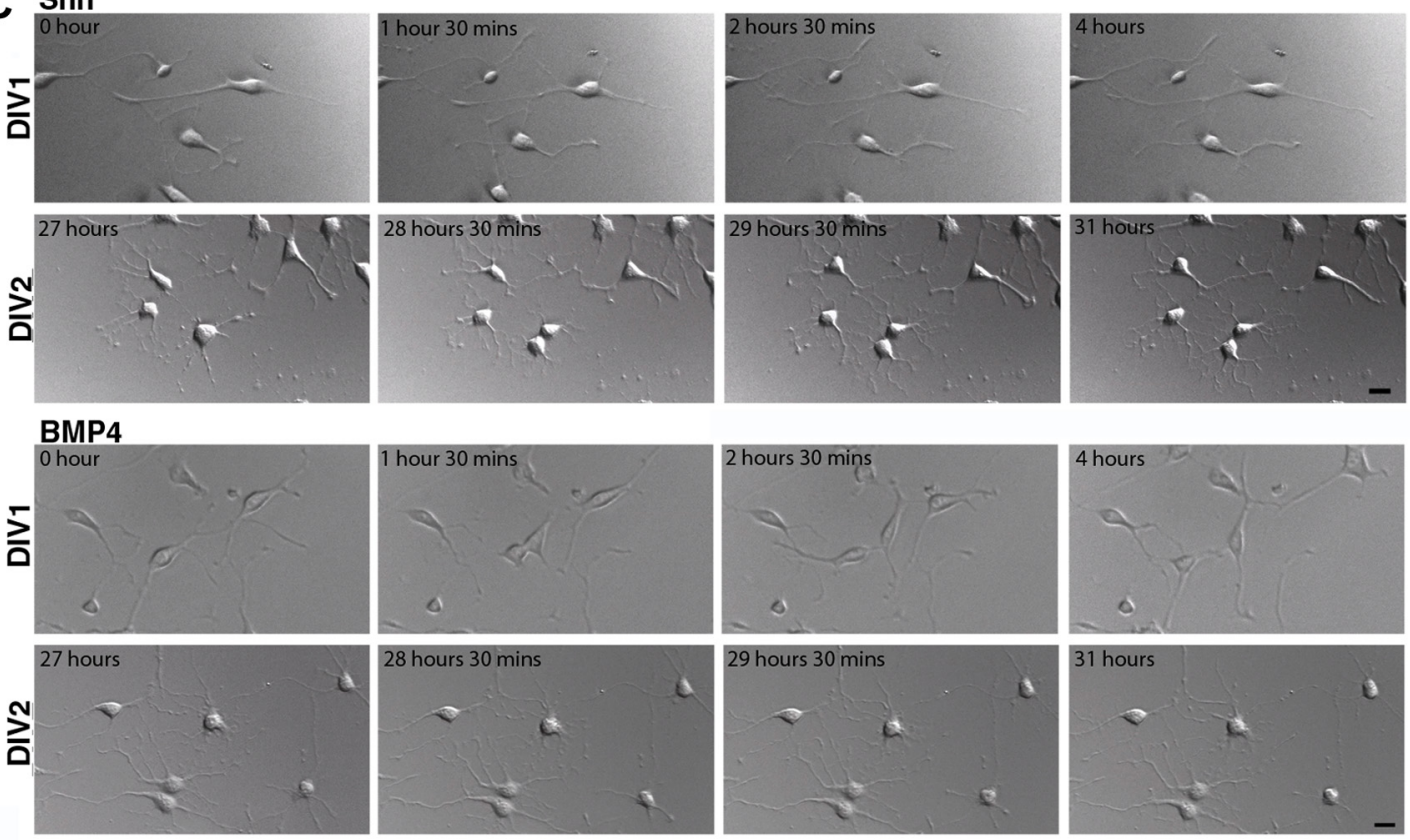

D
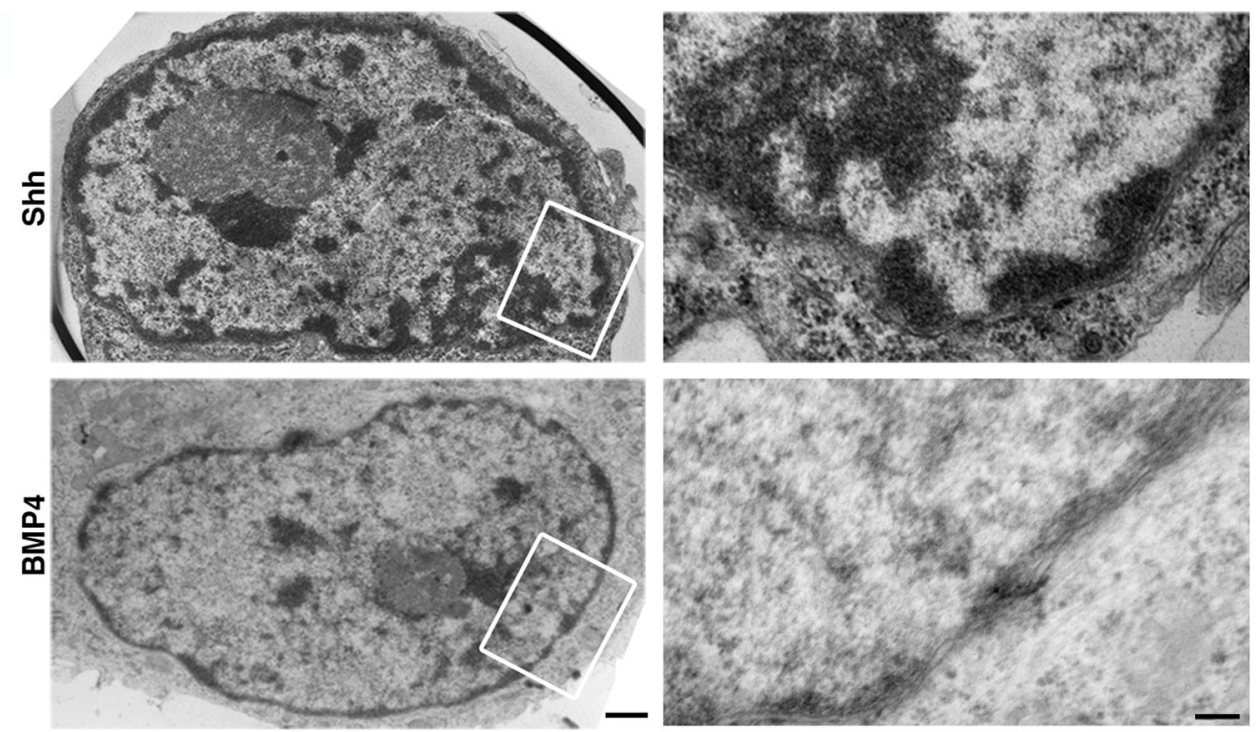

Figure 2. Shh and BMP4 differentially modulate the morphology and chromatin structure of treated OPCS. A, Caspase-3 staining showed no selective cell death in distinct cell types in response to Bmp4 or Shh treatment. B, The bar graph shows the total number of DAPI ${ }^{+}$cells counted in each well after 1, 2 or 3 days of Shh or BMP4 treatment. C, Morphological changes detected during a $4 \mathrm{~h}$ period of time-lapse imaging of OPC treated with either Shh or BMP4 for a $24 \mathrm{~h}$ (DIV1) or $48 \mathrm{~h}$ (DIV2) period. D, Electron microscopy of the nuclei of Shh and BMP4-treated cells. Note the electron-dense appearance of the Shh-treated cells, due to the formation of heterochromatin and the prevalence of euchromatin in BMP4-treated cells. Scale bars: $A, C, 20 \mu \mathrm{m} ; D$, left, $500 \mathrm{~nm} ;$ right, $120 \mathrm{~nm}$. 

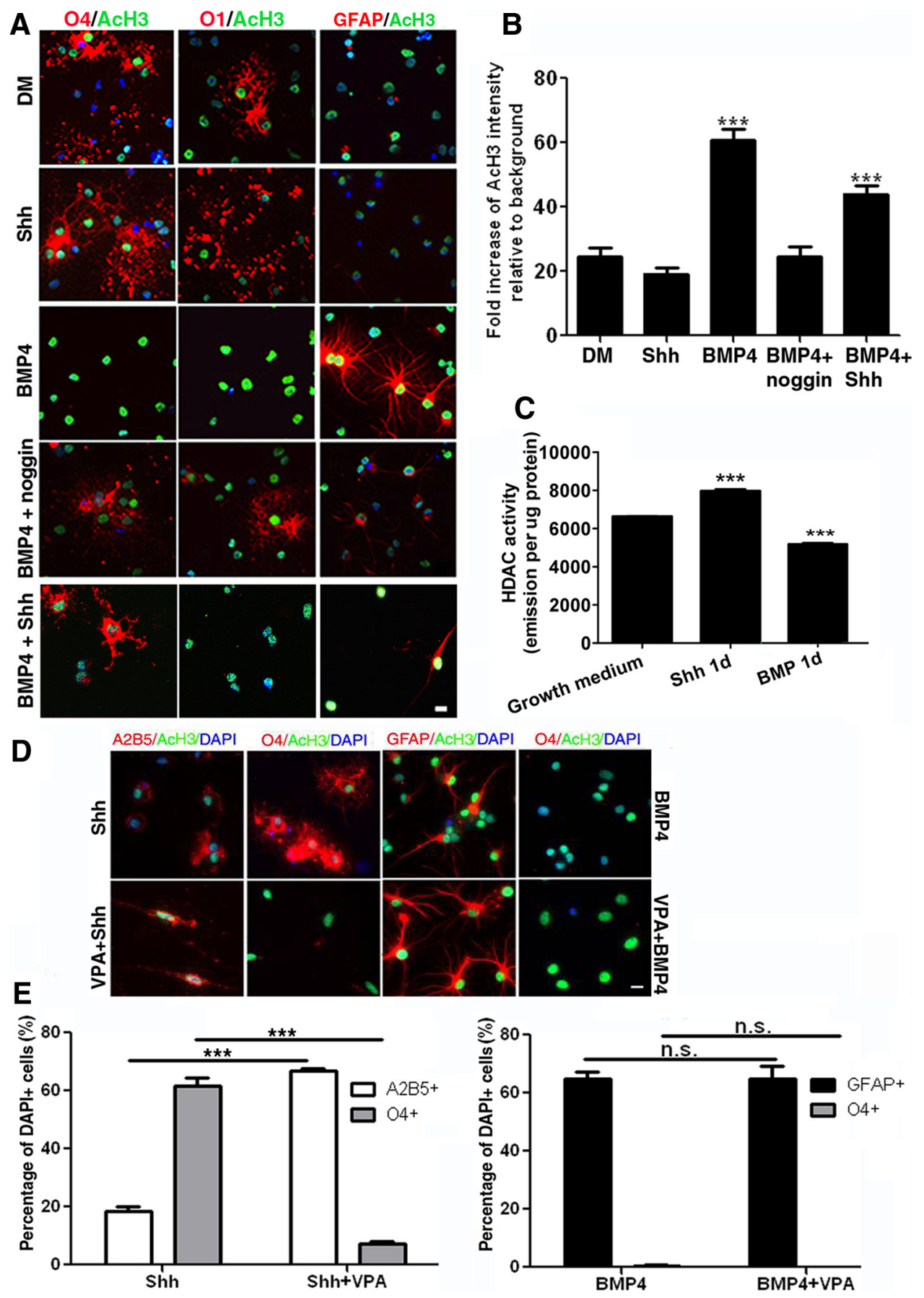

Figure 3. Shh and BMP4 have an opposing effect on nuclear histone acetylation. A, Immunocytochemistry of OPCs cultured for 5 days in chemically defined medium alone (DM), or with Shh (1 $\mu \mathrm{g} / \mathrm{ml})$, BMP4 (50 ng/ml), with BMP4 and Noggin $(1 \mu \mathrm{g} / \mathrm{ml}$ ) or with Shh and BMP4 together and stained with AcH3 (green) and the indicated lineage markers (red). DAPI (Blue) was used as nuclear counterstain. $\boldsymbol{B}$, The intensity of $\mathrm{ACH} 3$ in each treatment was measured by ImageJ software and is expressed as fold intensity relative to background. $\left.*^{* * *} p<0.001\right)$. C, The bar graph indicates the total HDAC enzymatic activity measured in cell lysates from primary OPCs cultures treated with Shh $(1 \mu \mathrm{g} / \mathrm{ml})$ or BMP4 $(50 \mathrm{ng} / \mathrm{ml})$ for 1 day. OPCs cultures in chemically defined medium supplemented with PDGF and FGF (Growth Medium) were used as baseline control (*** $p<0.001$ ). D. Confocal image of primary OPCs pretreated with the HDAC inhibitor VPA (1 mM) before the 5 day treatment with Shh or BMP4 and then costained with antibodies for acetyl-histone 3 ( $\mathrm{ACH} 3$, green), and for the cell lineage markers $04, \mathrm{~A} 2 \mathrm{~B} 5$, and GFAP to reveal cell identity. E, Bar graphs represent the $\mathrm{A2B5}^{+}, 04^{+}$, or GFAP ${ }^{+}$cell counts relative to total DAPI ${ }^{+}$nuclei $\left({ }^{* * *} p<0.001\right)$. Scale bars: $A, D, 10 \mu \mathrm{m}$.

with Shh or with BMP4 and its antagonist Noggin and intermediate levels of acetylation in OPCs that were cotreated with BMP4 and Shh (Fig. 3A,B). These immunocytochemical data were supported by measurement of nuclear HDAC enzymatic activity, which revealed higher deacetylation in OPCs treated with Shh for 24 h, compared with BMP4-treated cells (Fig. 3C). To evaluate the functional relevance of this finding, we treated cells with the pharmacological inhibitor of HDAC, valproic acid (Göttlicher,
2004), and evaluated the consequences on Shh-induced oligodendrogliogenesis or BMP4-induced astrogliogenesis (Fig. 3D,E). Pretreatment of cells with VPA for $24 \mathrm{~h}$ before exposure to Shh resulted in high levels of acetyl-histone $\mathrm{H} 3$ and prevented oligodendrocyte differentiation, while it did not affect BMP4-dependent astrogliogenesis (Fig. 3D,E). This suggested that HDAC activity is important for Shh-induced oligodendrocyte differentiation and dispensable for BMP4-induced astrogliogenesis. 

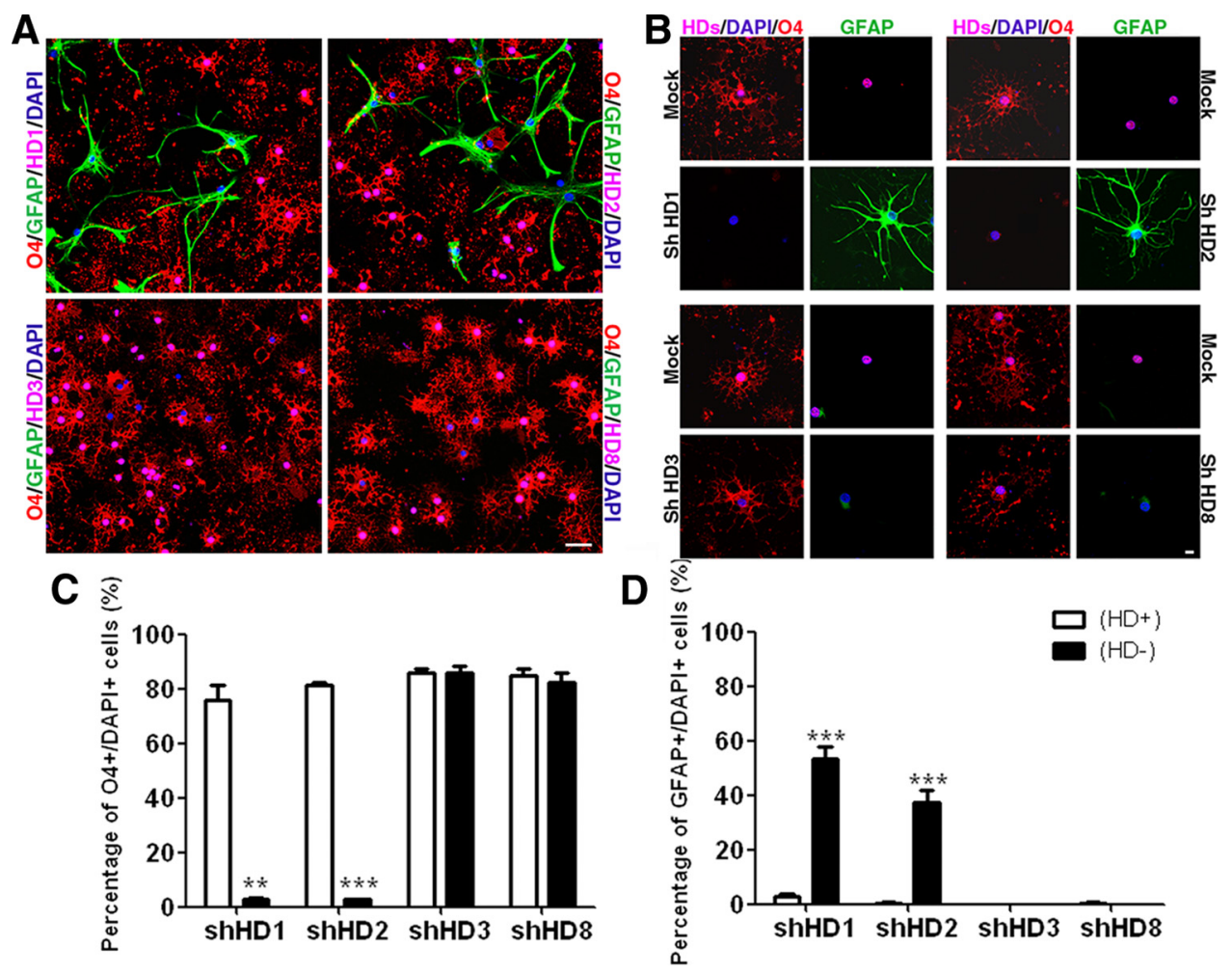

Figure 4. Hdac1 and Hdac 2 are necessary for Shh-induced oligodendrocyte lineage progression. Low $(\boldsymbol{A})$ and high $(\boldsymbol{B})$ magnification of immunoselected primary OPCs transduced with lentiviral vectors containing ShRNA to silence Hdac1, Hdac2, Hdac3 or Hdac8. Scrambled ShRNA lentiviral vectors were used as controls. OPCs were then treated with Shh (1 $\mu \mathrm{g} / \mathrm{ml})$ for 4 days and stained with antibodies specific for HDAC1, HDAC2, HDAC3 and HDAC8 to confirm silencing efficacy, and colabeled with 04 and anti-GFAP to test the effect on oligodendrocytic and astrocytic lineage respectively. C, D, Bar graphs show the percentage of $0^{+}(\boldsymbol{C})$ or GFAP ${ }^{+}(\boldsymbol{D})$ cells that were also HDAC-positive (white bars) or HDAC-negative (black bars; cell counts, $100-200$ cells/condition from two independent biological replicates). Note that silencing $\mathrm{Hdac} 1$ or Hdac2 but not $\mathrm{Hdac} 3$ or Hdac8 isoforms, inhibited oligodendrocyte lineage progression, while promoting the expression of the astrocyte lineage marker GFAP $\left({ }^{* *} p<0.01,{ }^{* * *} p<0.001\right)$. Scale bars: $A, 50 \mu \mathrm{m} ; \boldsymbol{B}, 10 \mu \mathrm{m}$.

Silencing of Hdac1 or Hdac2 prevents Shh-induced oligodendrocyte differentiation

To identify the specific HDAC isoforms downstream of Shh, we used a silencing approach with shRNA lentiviral constructs. Two days after infection with lentiviruses, OPC were incubated with Shh or BMP4 for 4 days, and silencing efficiency was confirmed by immunocytochemistry using antibodies specific for each HDAC isoform. Silencing of Hdacl or Hdac2 dramatically reduced the percentage of $\mathrm{O}^{+}$cells from $84.95 \%$ (in mock infected cultures) to $<3 \%$ (in silenced cells), and upregulated the astrocytic marker GFAP (Fig. 4A-D). Silencing of Hdac3 and $H d a c 8$ had no effect on cell lineage progression (Fig. 4A-D). These results indicated that Hdac1 and Hdac2 isoforms were critical for Shh-induced oligodendrocyte differentiation, and that their silencing reversed the effect of this morphogen and favored the expression of astrocyte-specific genes. Silencing of Hdac isoforms however, had no significant effect on BMP4induced astrocytic lineage progression and did not favor the expression of oligodendrocyte-specific genes in treated OPCs (Fig. $5 A-D)$. Therefore, Hdac1 and 2 are important for repressing astrocytic genes during Shh-induced OL differentiation, but they are dispensable for BMP4-induced astrogliogenesis.

Genome-wide transcriptomic analysis reveals important crosstalk among key developmental signaling pathways

To begin unraveling genome-wide changes induced by Shh or BMP4, we adopted an unbiased approach and conducted a genome-wide transcriptional profiling, using the Rat 230.2 Affymetrix Gene Chip and RNA isolated from OPCs that were treated with Shh, BMP4 or Shh and VPA for $24 \mathrm{~h}$. A heat map representation of gene expression profiles among the different groups of treatment (we averaged the results of three independent replicates for each treatment) was initially used to visualize the overall differences (Fig. 6 A). Of the 31,100 probe sets present in the array, BMP4 upregulated 8451 genes and downregulated 5497 compared with untreated OPCs. Shh treatment, in contrast downregulated only 634 genes and upregulated 604 genes, but the presence of VPA in the medium resulted in the upregulation of 6075 genes, compared with untreated OPCs. These findings were consistent with the results of HDAC enzymatic activity and revealed that the progression from OPC to oligodendrocytes requires fewer transcriptional changes than the conversion to astrocytes and that HDAC activity in OPCs is responsible for the repression of other lineage genes. To further identify the BMP4 and Shh target genes whose transcriptional regulation is mediated by HDAC activity, we computed the intersection set between the genes upregulated by BMP4 and Shh-VPA, but not upregulated by Shh (Fig. $6 B$ ). This rationale was based on the repressive role of HDAC activity on gene expression. The functional classification of the resulting set (containing a total of 1821 genes) was performed using DAVID gene ontology analysis (Huang da et al., $2009 a, b)$. Among the most relevant groups of differentially regulated genes in BMP4 and Shh-treated cells, we identified those involved in "developmental processes," "signaling cascade," "synaptic transmission," and "negative regulation of transcription" (Fig. 6C). Within these groups, we noticed several genes associated with Notch signaling (Jagged1, Hey1, Hey2, Hes1, Hes5) and others associated with Wnt signaling (Tbx3; Fig. 6D). 

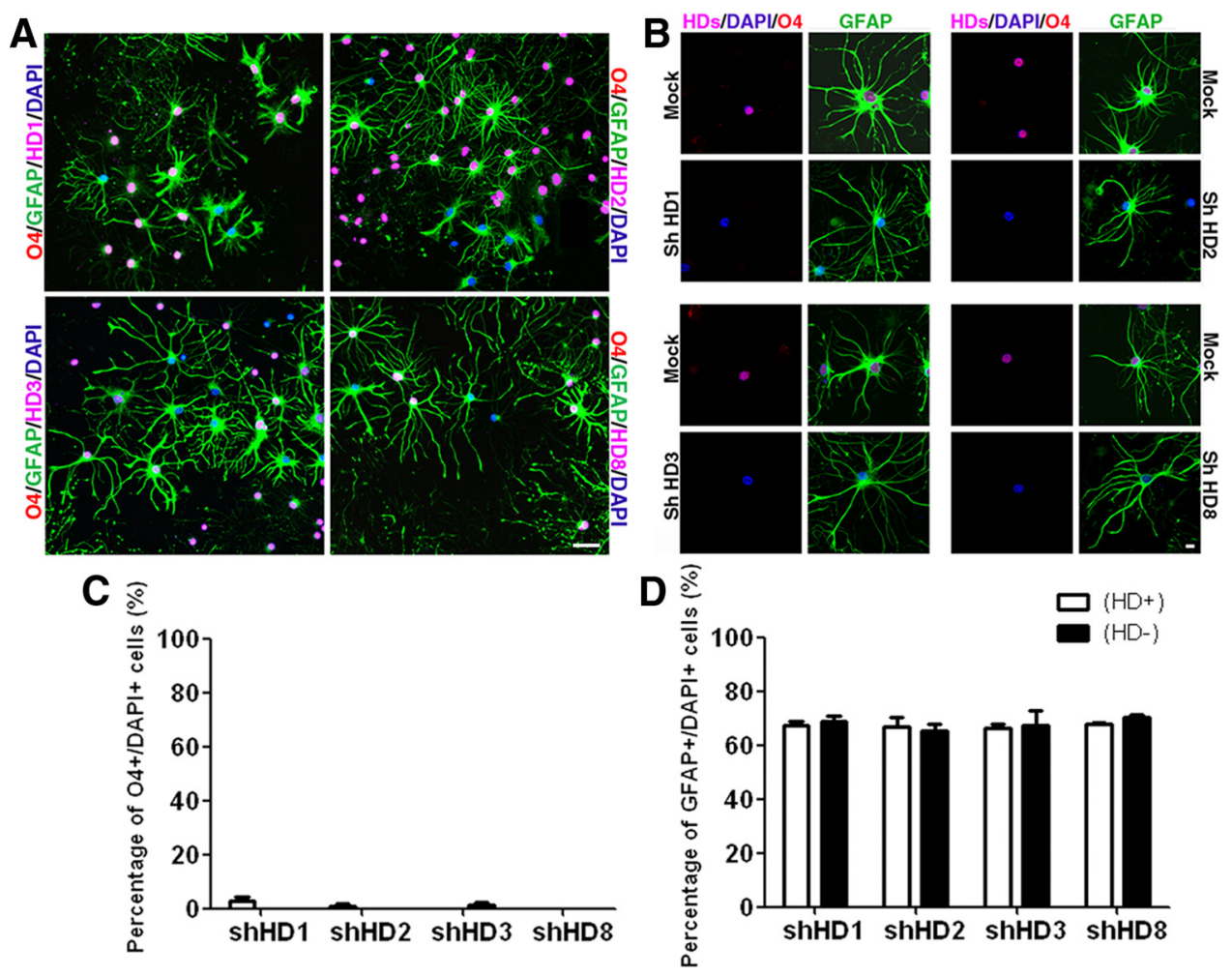

Figure 5. Silencing of Hdac isoforms has no effect on Bmp4-induced astrogliogenesis. Low $(\boldsymbol{A})$ and high $(\boldsymbol{B})$ magnification of immunoselected primary OPCs transduced with lentiviral vectors containing ShRNA to silence Hdac1, Hdac2, Hdac3 or Hdac8. Scrambled ShRNA lentiviral vectors were used as controls. OPCs were treated with Bmp4 (50 ng/ml) for $4 \mathrm{~d}$ and stained with antibodies specific for Hdac1, Hdac2, Hdac3, and Hdac8 (in red) to confirm silencing efficacy, and colabeled with 04 or anti-GFAP (green) to test the effect on oligodendrocytic and astrocytic lineage respectively. DAPI (blue) was used as nuclear counterstain. $\boldsymbol{C}, \boldsymbol{D}$, Bar graphs show the percentage of $04^{+}(\boldsymbol{C})$ or GFAP ${ }^{+}(\boldsymbol{D})$ cells that were also Hdac-positive (white bars) or Hdac-negative (black bars; cell counts, $100-200$ cells/condition in two independent biological replicates). Note that silencing all four Hdac isoforms had no effect on Bmp4-induced astrogliogenesis. Scale bars: $\boldsymbol{A}, 50 \mu \mathrm{m} ; \boldsymbol{B}, 10 \mu \mathrm{m}$.

These results were validated by RT-PCR using RNA samples isolated from cultured OPCs (Fig. 6E) and suggested the intriguing possibility that the inhibitory effect of BMP4 treatment on oligodendrocyte lineage progression, could be partially mediated by crosstalk with important developmental signals such as Wnt and Notch, due to modulation of the acetylation state of the identified target genes (Fig. 7A). To test this possibility, we performed immunoprecipitation (ChIP) on chromatin isolated from BMP4 or Shh-treated Oli-neu cells and precipitated with antibodies specific for acetyl-H3 (total or K9-specific) or for Hdac1 and Hdac2. We asked whether differences in the recruitment of Hdac or in the acetylation of histone $\mathrm{H} 3$ could be found in the target genes Hey1, or Hey2, or Tbx3. Interestingly, the regulatory elements of these genes include the consensus sequence for Shh-activated transcription factors (i.e., Gli, E-box and homeobox) very closely located to the consensus sequence for BMP4 activated transcription factors (i.e., SMAD; Fig. 7A). We therefore reasoned that activation of Shh or BMP4 pathways would result in differential regulation of target genes by differential recruitment of histonemodifying enzymes to the same region of chromatin. In agreement with our prediction, using Chromatin immunoprecipitation, we detected recruitment of $\mathrm{Hdacl}$ and $\mathrm{Hdac} 2$ at the regulatory regions of Hey1, Hey2, and Tbx3 in OPCs treated with Shh, which was consistent with lower levels of these transcripts (Fig. 7A). In contrast, BMP4-treated cells were characterized by high levels of these target genes and the increased transcription from these loci, nicely correlated with high levels of histone acetylation and decreased Hdac recruitment at the same chromatin loci. The results of this experiment further support the concept that histone acetylation of target genes is differentially modulated by BMP4 and
Shh. This interpretation was also supported by a competition experiment, where Shh-treated cells were treated with increasing concentrations of BMP4 (Fig. 7B). Since Id 2 and Id 4 are downstream genes of BMP4 pathways, we used the levels of these transcripts as positive controls for BMP4 treatment and measured the levels of Notch target genes in these conditions. The results are in agreement with the Chip data and show upregulation of Heyl and Hey 2 in a dose-dependent fashion in cells treated with Shh and increasing concentrations of BMP4 (Fig. 7B). Interestingly, the reverse experiment (i.e., constant concentration of BMP4 and increasing concentrations of Shh) was not equally effective (data not shown), therefore indicating that the presence of large transcriptional complexes containing histone acetyltransferase (like those recruited by BMP4 signaling pathway) are harder to displace than repressive complexes containing Hdac (like those found in Shh-treated cells).

To further exclude the possibility that the BMP4-induced expression of Wnt and Notch target genes was caused by the presence of Wnt or Notch ligands in cultured OPCs, we pretreated cells either with specific pharmacological inhibitors of the Wnt or Notch pathway before Bmp4 treatment. To page Wnt signaling we used the tankyrase inhibitor XAV939 (to decrease $\beta$-catenin availability, due to axin 2 stabilization) or a small molecule inhibiting the binding of $\beta$-catenin to Tcf4 (i.e., iCRT14) and then measured the levels of $T b \times 3$ transcripts. To page the Notch pathway, we used SAHM1, an inhibitor of the assembly of the NICD activator complex, and then measured the levels of Hey1, Hey2, and Hes5 transcripts (Fig. 7C). The levels of Tbx3 induced by BMP4 treatment were not affected by the presence of Wnt inhib- 

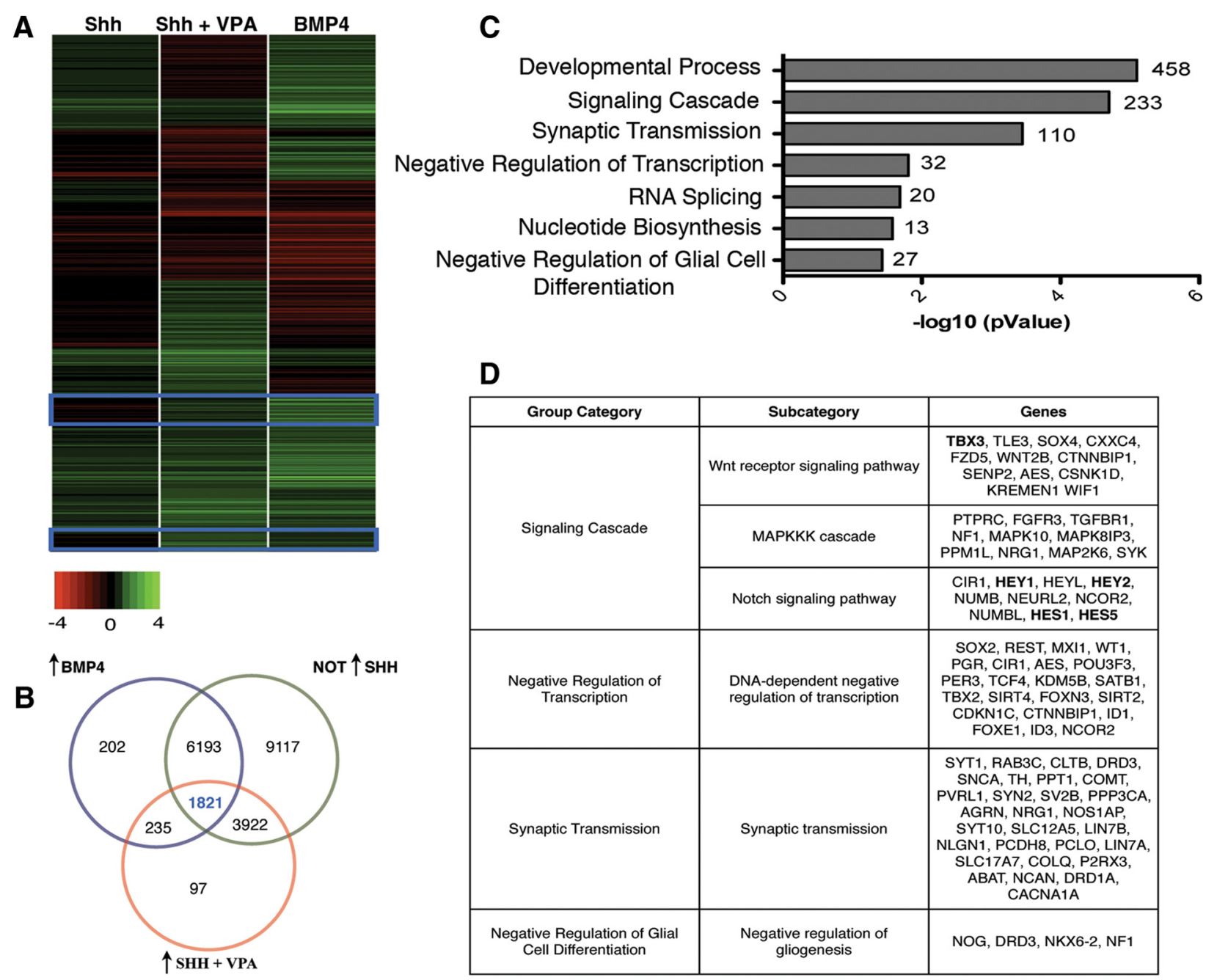

\begin{tabular}{|c|c|c|}
\hline Group Category & Subcategory & Genes \\
\hline \multirow{3}{*}{ Signaling Cascade } & Wnt receptor signaling pathway & $\begin{array}{c}\text { TBX3, TLE3, SOX4, CXXC4, } \\
\text { FZD5, WNT2B, CTNNBIP1, } \\
\text { SENP2, AES, CSNK1D, } \\
\text { KREMEN1 WIF1 }\end{array}$ \\
\hline & MAPKKK cascade & $\begin{array}{l}\text { PTPRC, FGFR3, TGFBR1, } \\
\text { NF1, MAPK10, MAPK8IP3, } \\
\text { PPM1L, NRG1, MAP2K6, SYK }\end{array}$ \\
\hline & Notch signaling pathway & $\begin{array}{l}\text { CIR1, HEY1, HEYL, HEY2, } \\
\text { NUMB, NEURL2, NCOR2, } \\
\text { NUMBL, HES1, HES5 }\end{array}$ \\
\hline $\begin{array}{l}\text { Negative Regulation of } \\
\text { Transcription }\end{array}$ & $\begin{array}{l}\text { DNA-dependent negative } \\
\text { regulation of transcription }\end{array}$ & $\begin{array}{l}\text { SOX2, REST, MXI1, WT1, } \\
\text { PGR, CIR1, AES, POU3F3, } \\
\text { PER3, TCF4, KDM5B, SATB1, } \\
\text { TBX2, SIRT4, FOXN3, SIRT2, } \\
\text { CDKN1C, CTNNBIP1, ID1, } \\
\text { FOXE1, ID3, NCOR2 }\end{array}$ \\
\hline Synaptic Transmission & Synaptic transmission & $\begin{array}{l}\text { SYT1, RAB3C, CLTB, DRD3, } \\
\text { SNCA, TH, PPT1, COMT, } \\
\text { PVRL1, SYN2, SV2B, PPP3CA, } \\
\text { AGRN, NRG1, NOS1AP, } \\
\text { SYT10, SLC12A5, LIN7B, } \\
\text { NLGN1, PCDH8, PCLO, LIN7A, } \\
\text { SLC17A7, COLQ, P2RX3, } \\
\text { ABAT, NCAN, DRD1A, } \\
\text { CACNA1A }\end{array}$ \\
\hline $\begin{array}{l}\text { Negative Regulation of Glial } \\
\text { Cell Differentiation }\end{array}$ & $\begin{array}{l}\text { Negative regulation of } \\
\text { gliogenesis }\end{array}$ & NOG, DRD3, NKX6-2, NF1 \\
\hline
\end{tabular}

E

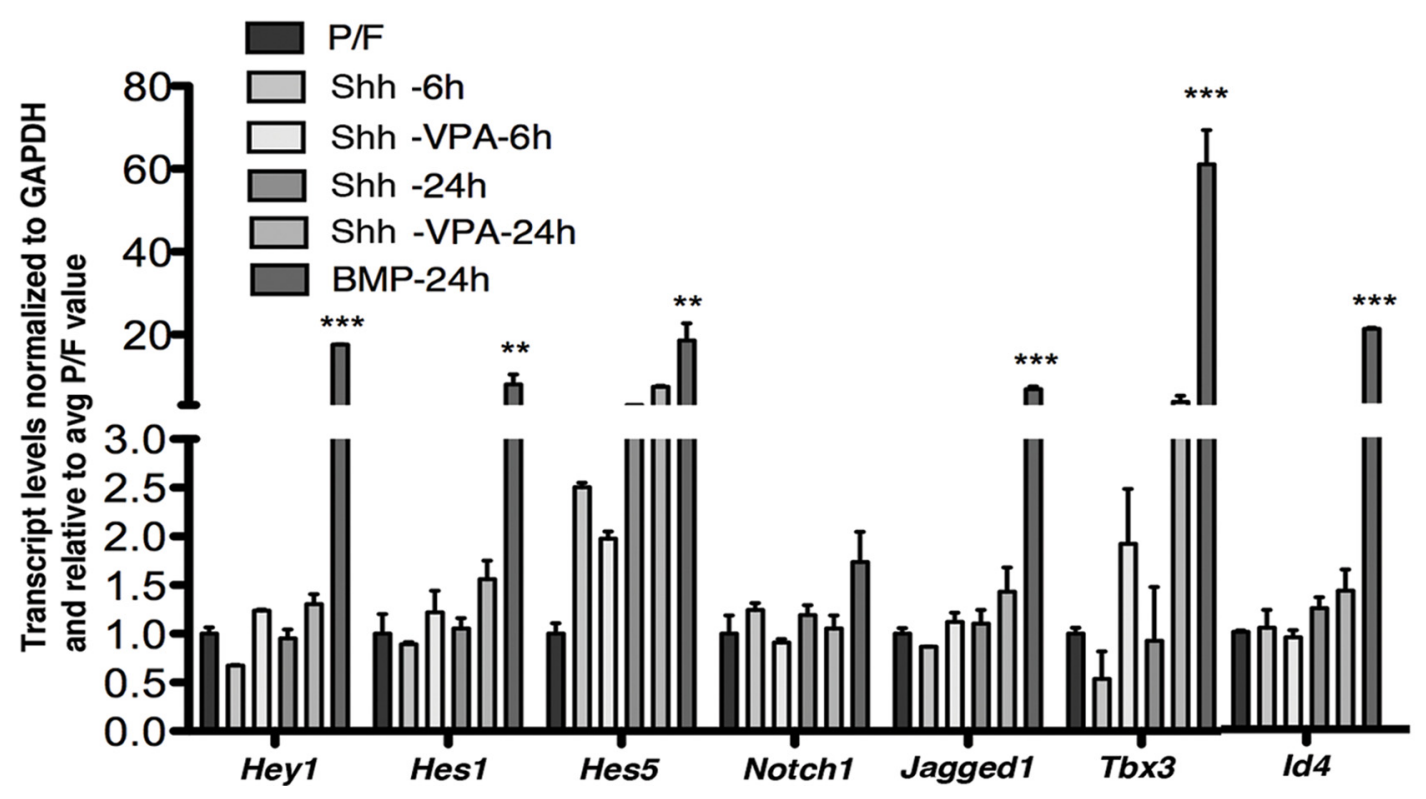

Figure 6. Differential effect of Shh or BMP4 on the transcriptome of treated OPCs. A, Heat map representation of the microarray data obtained from OPCs treated with Shh, BMP4 or Shh with VPA for $24 \mathrm{~h}$ normalized to the control (P/F). B, Venn Diagram that illustrates the number of genes upregulated by BMP4, upregulated by Shh with VPA and not upregulated by Shh. The intersection for the three sets is highlighted. C, Representation of the most significant gene ontology terms that were enriched in the intersection set of the genes upregulated by BMP4, upregulated by Shh with VPA and not upregulated by Shh. $\boldsymbol{D}$, The table shows representative enriched genes within the indicated ontology terms. $\boldsymbol{E}$, Validation of the microarray data by quantitative real time PCR on RNA

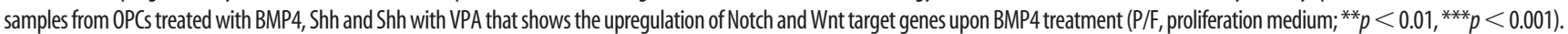



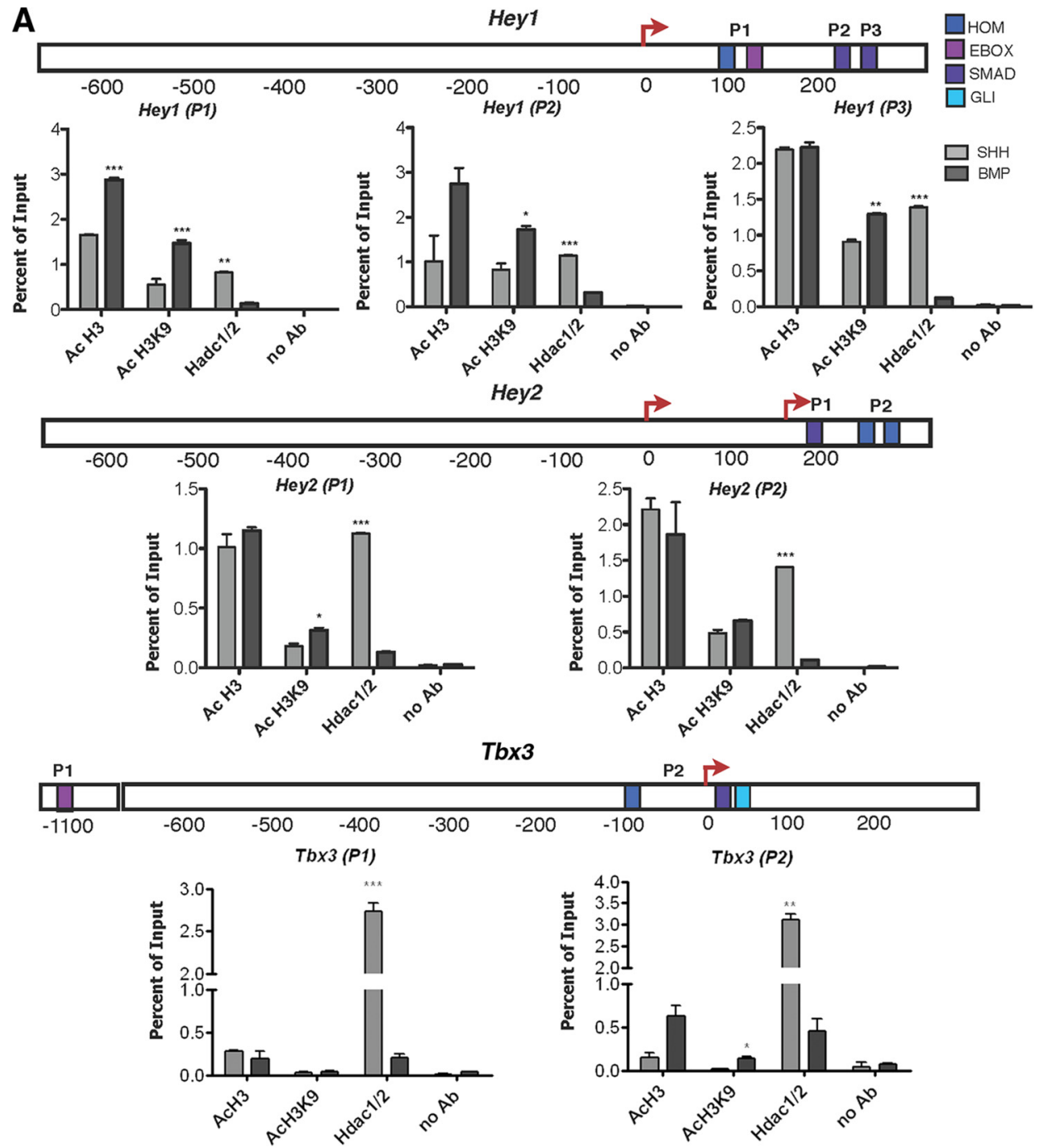

B
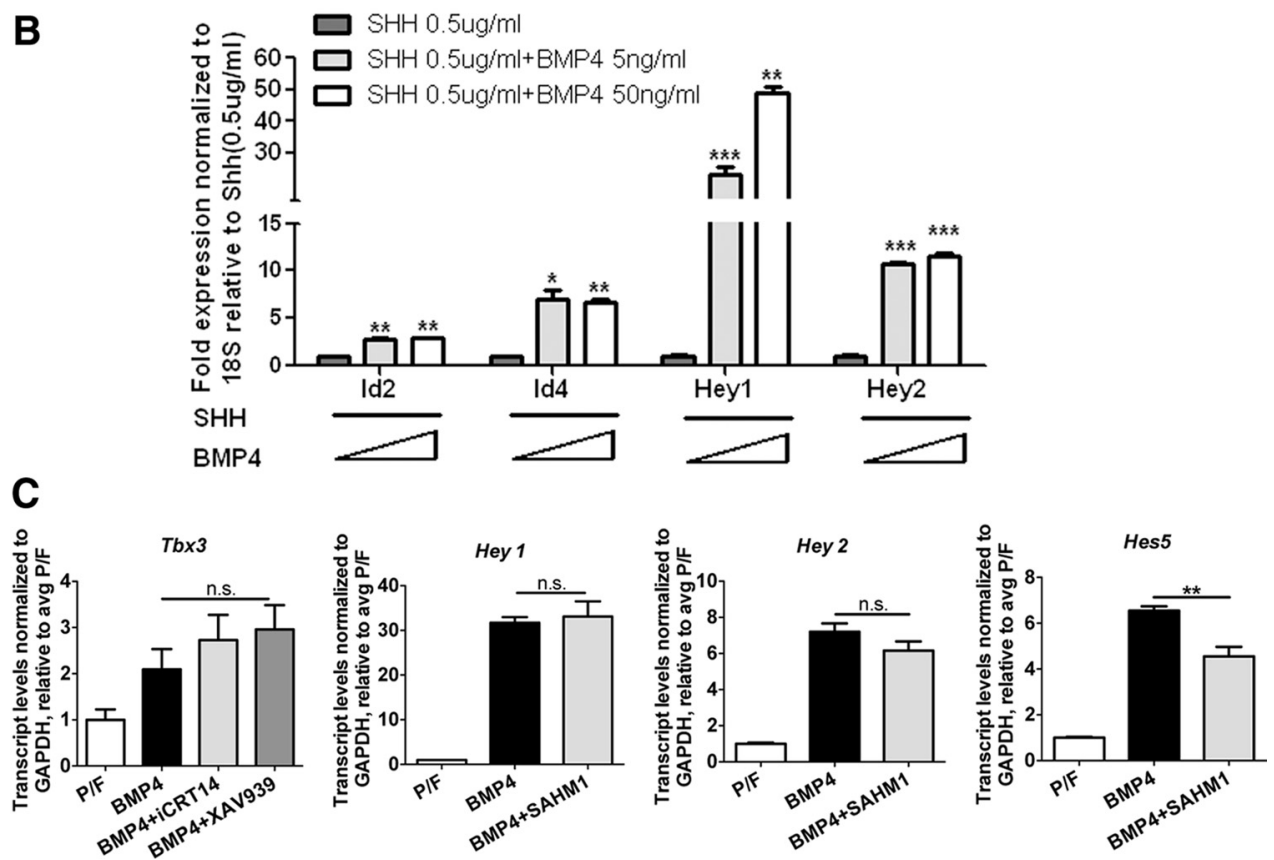

Figure 7. BMP4 regulates histone acetylation of Notch and Wnt target genes. A, Quantitative ChIP on chromatin samples isolated from cells treated with Shh or BMP4 for $24 \mathrm{~h}$ and immunoprecipitated with antibodies specific for pan acetyl H3 (ACH3), for acetyl K9 (AcH3K9) and for Hdac1 and Hdac2 (HDAC1/2). The schematics above each ChIP experiment indicate (Figurelegend continues.) 

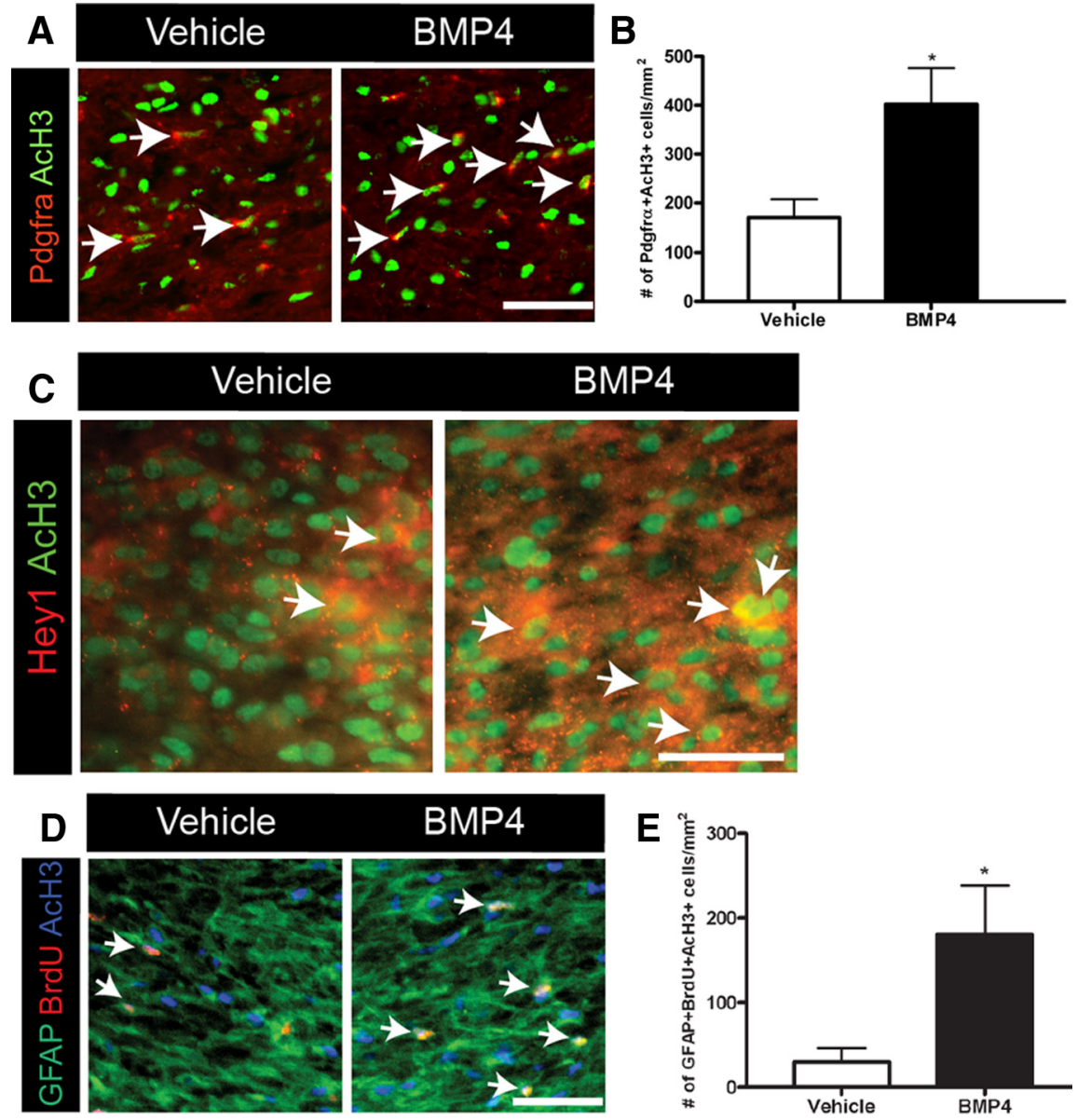

Figure 8. BMP4 infusion increases numbers of $O P C s$ and proliferating astrocytes with histone acetylation in the demyelinated corpus callosum. Mice were infused with either vehicle or BMP4 for 5 days beginning at 4 weeks of cuprizone. $\boldsymbol{A}$, Immunostaining of PDGFRA (red) and $\mathrm{AcH} 3$ (green) in the demyelinated corpus callosum. Representative PDGFRA $^{+} \mathrm{ACH}_{3}{ }^{+}$double-positive cells are indicated by arrows. $B$, Bar graph shows the quantification of PDGFRA ${ }^{+} \mathrm{AcH}^{+}$ double-positive cells per $\mathrm{mm}^{2}$ in the midline corpus callosum. $\boldsymbol{C}$, In situ hybridization of Hey 1 probe (red) and immunostaining of $\mathrm{AcH} 3$ (green) in the demyelinated corpus callosum. Representative Hey ${ }^{+} \mathrm{AcH} 3{ }^{+}$double-positive cells are indicated by arrows. D, Immunostaining of GFAP (green), BrdU (red) and AcH3 (blue) in the demyelinated corpus callosum. Representative $\mathrm{GFAP}^{+} \mathrm{BrdU}^{+} \mathrm{AcH} 3{ }^{+}$triple-positive cells are indicated by arrows. $\boldsymbol{E}$, Bar graph shows the quantification of $\mathrm{GFAP}^{+} \mathrm{BrdU}^{+} \mathrm{AcH} 3{ }^{+}$triple-positive cells per $\mathrm{mm}^{2}$ in the midline corpus callosum. Data represent means $\pm \mathrm{SEM}$; $(n=$ 3-4 mice, $\left.{ }^{*} p<0.05\right)$. Scale bars: $A, C, D, 50 \mu \mathrm{m}$.

itors of $\beta$-catenin. With the exception of Hes5 transcript levels, which were reduced by SAHM1 treatment, the other Notchdependent genes (Hey1, Hey2) were expressed at similar levels in cells treated with BMP4 in the absence and presence of the Notch inhibitor (Fig. 7). Together with the ChIP results, these data strongly support the interpretation of a direct effect of BMP4 signaling on Notch and Wnt target genes.

(Figure legend continued.) the regions of the Hey1, Hey2 and Tbx3 loci, the relative primer pairs $(P 1, P 2, P 3)$ used to test each regions and the relative location of the SMAD, Homeobox, GLI and $E$ box binding sites (colored boxes). Values are expressed as the relative enrichment of the immunoprecipitated chromatin over input levels. $\boldsymbol{B}, \mathrm{OPCS}$ were treated with constant dose of Shh $(0.5 \mu \mathrm{g} / \mathrm{ml})$ and increased doses of BMP4 $(0 \mathrm{ng} / \mathrm{ml}, 5 \mathrm{ng} / \mathrm{ml}$ and $50 \mathrm{ng} / \mathrm{ml})$ for $24 \mathrm{~h}$, gene expressions were evaluated by real-time $\mathrm{PCR}\left({ }^{*} p<0.05,{ }^{* *} p<0.01\right.$, $\left.{ }^{* * *} p<0.001\right)$. C, Realtime PCR on RNA samples from the same cells either kept proliferating in the presence of PDGF and FGF (P/F) or pretreated with the Wnt (iCRT14, XAV939) or Notch inhibitors (SAHM1) and then exposed to BMP4 for $24 \mathrm{~h}$. The bar graphs represent the average \pm SEM of three independent determinations $\left({ }^{*} p<0.05,{ }^{* *} p<0.01,{ }^{* * *} p<0.001\right)$.
To define whether BMP4 similarly modulated histone acetylation and the expression of Notch target genes (i.e., Heyl) in vivo, we studied OPCs in the adult brain of mice during myelin repair from cuprizone-induced demyelination. We have previously reported that repair occurs from the fourth week of cuprizone treatment and therefore mice were infused with vehicle or BMP4 into the lateral ventricle, using osmotic minipumps for 5 days, starting during the fourth week of cuprizone treatment. Acetylated-histone $\mathrm{H} 3$ was visualized by immunohistochemistry followed by confocal analysis and Heyl transcripts were detected using in situ hybridization in the demyelinated corpus callosum at the end of the 5 days of BMP4 infusion. In agreement with the results in cultured OPCs, we also detected increased number of PDGFRA ${ }^{+} \mathrm{AcH}_{3}{ }^{+}$ double-positive cells in BMP4 infused mice compared with vehicle controls (Fig. $8 A, B)$. These cells were also characterized by the presence of Heyl transcripts, as shown by in situ hybridization (Fig. 8C). To further assess the consequences of BMP4 treatment on lineage progression we also performed GFAP staining and measured the number of immunoreactive cells, 1 week following the infusion. In agreement with previous reports (Sabo et al., 2011), we detected increased numbers of astrocytes and decreased numbers of oligodendrocytes. Within the demyelinated lesion, BMP4 infusion increased the number of astrocytes that were immunoreactive for acetylated-histone $\mathrm{H} 3$ and BrdU (Fig. $8 D, E)$. Together these results are in agreement with the data in cultured oligodendrocytes and indicate that the actual levels of BMP4 surrounding areas of demyelination, might significantly impact repair.

\section{Discussion}

\section{BMP4 and Shh in OPCs differentially modulate histone} acetylation

Differentiation of OPCs results from the integration of extracellular signals and the chromatin state of a cell. OPCs are characterized by euchromatin and amenable to "accept" environmental signals (i.e., Shh, BMP4, Notch, Wnt) to modulate gene expression and differentiation. Previous studies reported impaired OPC generation after Shh loss-of-function (Davies and Miller, 2001) and ectopic oligodendrogenesis after Shh gain-of-function (Nery et al., 2001; Yung et al., 2002). BMP4 was shown to increase the number of astrocytes at the expenses of oligodendrocytes (Gomes et al., 2003) and inhibit later stages of differentiation (Grinspan et al., 2000) and myelin gene expression (Wada et al., 2000; Miller et al., 2004; Samanta and Kessler, 2004; See et al., 2004). In this study we describe the effect of BMP4 and Shh on nuclear chromatin and gene expression in OPCs. We show that Shh activates Hdac activity and promotes oligodendrocyte differentiation and peripheral chromatin compaction, while BMP4 
prevents oligodendrogliogenesis and favors histone acetylation on the promoter of several transcriptional inhibitors (including genes that are known down-stream effectors of Notch or Wnt).

BMP4 signals via serine-threonine receptors (BMPRIa, Ib and II) that activate Smad1/5/8 proteins (R-Smads), associate with the common mediator-Smad 4 (co-Smad; Nohe et al., 2004; Liu and Niswander, 2005) and activate gene expression by interacting with transcriptional coactivators (Feng et al., 1998; Janknecht et al., 1998). Binding of Shh to the Ptchd1 receptor, releases the inhibition of the transmembrane protein Smoothened and allows the translocation of Gli2/3 transcriptional activators into the nucleus, where they induce the expression of Shh-target genes.

A competitive mechanism between Shh and BMP4 was identified in OPCs (Samanta and Kessler, 2004) and involved the functional sequestration of Shh target molecules (i.e., Olig2) by the inhibitors of differentiation protein Id2 and Id4, which are induced by BMP4 (Rivera and Murre, 2001; Wang et al., 2001; Yokota, 2001; Kondo, 2009). In mouse cerebellar cultures, in contrast, BMPs interfere with the Shh-induced proliferation by decreasing the levels of Gli1 and Smo (Rios et al., 2004), while in the chick spinal cord, BMP has been shown to repress Shh target genes Olig2 and Nkx2.2 (Mekki-Dauriac et al., 2002). In the adult brain the inhibitory effect of BMP4 on oligodendrogliogenesis has been attributed to the effect of Smad4 on the expression of Olig2. In a series of elegant studies on mice lacking Smad4 in neural stem cells, higher numbers of Olig2 ${ }^{+}$cells and oligodendrocytes were detected, a finding that was replicated by infusion of noggin (Colak et al., 2008).

This manuscript identifies an additional layer of regulation of OPC differentiation by Shh and BMP4 by exerting opposite effect on histone acetylation and chromatin compaction, thereby inducing genome-wide changes of OPC transcriptome.

\section{Transcriptomic analysis of BMP4-treated oligodendrocyte progenitors reveals the presence of Notch and Wnt target genes}

Our analysis revealed that BMP4 treatment favored a relaxed and transcriptionally competent chromatin structure associated with the induction of thousands of genes during the first $24 \mathrm{~h}$. In contrast, Shh-treatment activated Hdac activity and induced peripheral condensation of chromatin and induced repression and activation of hundred genes during the progression from OPC to oligodendrocytes. A potential interpretation of these findings is that Shh favors Hdac activity to allow oligodendrocyte lineage differentiation while BMP4 decreases Hdac activity and massively turns on the transcription of large gene programs that inhibit oligodendrocyte while favoring astrocyte generation. In support of this interpretation, we noticed that $73 \%$ of the BMP 4 activated genes corresponded to transcripts that were repressed by Hdac activity in oligodendrocytes. Silencing of Hdacl or Hdac2"released" this inhibition and resulted in the expression of astrocytic genes in Shhtreated cultures. Gene ontology analysis of the genes activated by $\mathrm{BMP} 4$ and repressed during the progression of OPC to oligodendrocytes, revealed genes involved in synaptic transmission, Notch and Wnt signaling pathways.

The BMP4-mediated induction of Wnt target genes was not surprising if we take into consideration the fact that BMP4 and Wnt are both expressed in dorsal regions of the developing neural tube and have both been shown to prevent oligodendrocyte differentiation in vivo (Shimizu et al., 2005; Kim et al., 2008; Fancy et al., 2009; Feigenson et al., 2009) and in vitro (Feigenson et al., 2011). In addition, OPCs lacking both BMPr1A and BMPr1b lost also the ability to respond to Wnt3a, while cells lacking $\beta$-catenin, an essential component of the Wnt pathway, retained their ability to respond to BMP4, further supporting the existence of a cross talk between BMP4 and Wnt (Feigenson et al., 2011). These data suggest that BMP4 treatment may render the cell more responsive to the inhibitory effect of Wnt, possibly by upregulating specific transcription factors, such as Tbx3 (Eblaghie et al., 2004), although the enhanced responsiveness remains to be experimentally tested. $T b \times 3$ encodes for a T-box-containing transcription factor, whose expression has been previously shown to be differentially regulated by BMP4 and Shh during specification of the identity of the posterior digits in the chick (Suzuki et al., 2004). Modulation of Tbx3 levels by BMP4 was reported in the developing retina (Behesti et al., 2006) and in the adult brain (Eriksson and Mignot, 2009), although its role in the nervous system has not been clearly elucidated, one possibility is that Tbx factors act as repressors of Shh (Manning et al., 2006), thereby decreasing the responsiveness of progenitors to ventral-derived signals. Alternatively, Tbx3 could suppress the Arflocus, which encodes for tumor suppressor and cell cycle inhibitory molecules and thereby favor proliferation (Brummelkamp et al., 2002).

Our study also detected the BMP4-mediated induction of Notch target genes, including Jagged 1 and the downstream effectors Hey1, Hey2, Hes1, Hes5. The role of Notch signaling in gliogenesis (Gaiano et al., 2000) is well established and in the oligodendrocyte lineage, Notch has been linked to maintenance of the undifferentiated progenitor state during development (Wang et al., 1998) and defective repair after demyelination in the adult brain (Zhang et al., 2009). The downstream targets belong to the Hairy Enhancer of Split family of bHLH transcriptional repressors whose role has been linked to maintenance of neural stem cells (Kageyama and Nakanishi, 1997; Wang et al., 1998; Lai, 2004), inhibition of oligodendrocyte differentiation (Wang et al., 1998) and myelin gene expression (Liu et al., 2006) and possibly increased proliferation, consequent to the repression of $p 27 \mathrm{Kip} 1$ (Havrda et al., 2006), a cell cycle inhibitor which has been previously shown to modulate cell cycle exit in OPCs (CasacciaBonnefil et al., 1997, 1999).

\section{Role of BMP4 in the adult brain and potential implications of our findings for repair}

Finally, it is important to mention that inhibition of BMP signaling has been implicated for oligodendrogliogenesis during human development (Sim et al., 2006) and high BMP4 levels have been reported in human brains from patients with multiple sclerosis (Deininger et al., 1995). High levels of BMP4 were also detected in animal models of spinal cord injury, and correlated with increased astrocyte generation (Wang et al., 2011) and severe glial scar formation (Fuller et al., 2007). BMP4 levels were also upregulated in mice with induced experimental allergic encephalomyelitis (Ara et al., 2008) and in the cuprizone-induced model of toxic demyelination and they correlated with a dosedependent increase in astrocyte numbers at the expenses of oligodendrocytes (Cate et al., 2010). The inhibition of BMP4 signaling by infusion of Noggin reversed the effect and reduced the astrocyte numbers (Cate et al., 2010) while promoting oligodendrocyte regeneration and remyelination (Sabo et al., 2011). In addition to the role of BMP4 in astrogliogenesis, it is important to remember that BMP also modulates adult neurogenesis in neural stem cells residing in the subventricular zone (SVZ) and that ventricular infusion of noggin favors oligodendrocyte generation, at the expenses of neurogenesis (Colak et al., 2008). Recent studies in the SVZ after lysolecithin model of demyelination in the corpus callosum have further revealed that another inhibitor 
of BMP signaling, chordin, is upregulated and that this favors the transition from neurogenesis to gliogenesis, although both, astrogliogenesis and oligodendrogliogenesis were favored (Jablonska et al., 2010). Our studies contribute to this field by revealing an additional role of BMP4 in the adult brain, where it also promotes the expression of Notch target genes, presumably involved in the proliferative response to BMP4 infusion.

In conclusion, our study reveals histone acetylation and chromatin changes as points of convergence for Shh and BMP4 in OPC differentiation. We demonstrate that Hdac activity is required for the suppression of transcriptional programs activated in other lineages during Shh-induced differentiation. In contrast, the effect of BMP4 on the oligodendrocyte lineage does not rely on repressive regulation of genes; rather, it requires extensive activation of gene expression and the upregulation of downstream signaling molecules of pathways that also exert a negative modulation of oligodendrocyte differentiation. Together these results suggest that inhibitory strategies aimed at dampening BMP4 effect may be important to favor myelin formation in the developing and diseased brain.

\section{References}

Ara J, See J, Mamontov P, Hahn A, Bannerman P, Pleasure D, Grinspan JB (2008) Bone morphogenetic proteins 4, 6, and 7 are up-regulated in mouse spinal cord during experimental autoimmune encephalomyelitis. J Neurosci Res 86:125-135.

Back SA, Craig A, Kayton RJ, Luo NL, Meshul CK, Allcock N, Fern R (2007) Hypoxia-ischemia preferentially triggers glutamate depletion from oligodendroglia and axons in perinatal cerebral white matter. J Cereb Blood Flow Metab 27:334-347.

Baron W, Metz B, Bansal R, Hoekstra D, de Vries H (2000) PDGF and FGF-2 signaling in oligodendrocyte progenitor cells: regulation of proliferation and differentiation by multiple intracellular signaling pathways. Mol Cell Neurosci 15:314-329.

Barres BA, Lazar MA, Raff MC (1994) A novel role for thyroid hormone, glucocorticoids and retinoic acid in timing oligodendrocyte development. Development 120:1097-1108.

Behesti H, Holt JK, Sowden JC (2006) The level of Bmp4 signaling is critical for the regulation of distinct $\mathrm{T}$-box gene expression domains and growth along the dorso-ventral axis of the optic cup. BMC Dev Biol 6:62.

Brummelkamp TR, Kortlever RM, Lingbeek M, Trettel F, MacDonald ME, van Lohuizen M, Bernards R (2002) TBX-3, the gene mutated in UlnarMammary Syndrome, is a negative regulator of p19ARF and inhibits senescence. J Biol Chem 277:6567-6572.

Cahoy JD, Emery B, Kaushal A, Foo LC, Zamanian JL, Christopherson KS, Xing Y, Lubischer JL, Krieg PA, Krupenko SA, Thompson WJ, Barres BA (2008) A transcriptome database for astrocytes, neurons, and oligodendrocytes: a new resource for understanding brain development and function. J Neurosci 28:264-278.

Casaccia-Bonnefil P, Tikoo R, Kiyokawa H, Friedrich V Jr, Chao MV, Koff A (1997) Oligodendrocyte precursor differentiation is perturbed in the absence of the cyclin-dependent kinase inhibitor p27Kip1. Genes Dev 11:2335-2346.

Casaccia-Bonnefil P, Hardy RJ, Teng KK, Levine JM, Koff A, Chao MV (1999) Loss of p27Kip1 function results in increased proliferative capacity of oligodendrocyte progenitors but unaltered timing of differentiation. Development 126:4027-4037.

Cate HS, Sabo JK, Merlo D, Kemper D, Aumann TD, Robinson J, Merson TD, Emery B, Perreau VM, Kilpatrick TJ (2010) Modulation of bone morphogenic protein signalling alters numbers of astrocytes and oligodendroglia in the subventricular zone during cuprizone-induced demyelination. J Neurochem 115:11-22.

Colak D, Mori T, Brill MS, Pfeifer A, Falk S, Deng C, Monteiro R, Mummery C, Sommer L, Götz M (2008) Adult neurogenesis requires Smad4mediated bone morphogenic protein signaling in stem cells. J Neurosci 28:434-446.

Davies JE, Miller RH (2001) Local sonic hedgehog signaling regulates oligodendrocyte precursor appearance in multiple ventricular zone domains in the chick metencephalon. Dev Biol 233:513-525.
Deininger M, Meyermann R, Schluesener H (1995) Detection of two transforming growth factor-beta-related morphogens, bone morphogenetic proteins- 4 and -5 , in RNA of multiple sclerosis and Creutzfeldt-Jakob disease lesions. Acta Neuropathol 90:76-79.

Dennis G Jr, Sherman BT, Hosack DA, Yang J, Gao W, Lane HC, Lempicki RA (2003) DAVID: Database for Annotation, Visualization, and Integrated Discovery. Genome Biol 4:P3.

Dugas JC, Tai YC, Speed TP, Ngai J, Barres BA (2006) Functional genomic analysis of oligodendrocyte differentiation. J Neurosci 26:10967-10983.

Eblaghie MC, Song SJ, Kim JY, Akita K, Tickle C, Jung HS (2004) Interactions between FGF and Wnt signals and Tbx3 gene expression in mammary gland initiation in mouse embryos. J Anat 205:1-13.

Eriksson KS, Mignot E (2009) T-box 3 is expressed in the adult mouse hypothalamus and medulla. Brain Res 1302:233-239.

Fancy SP, Baranzini SE, Zhao C, Yuk DI, Irvine KA, Kaing S, Sanai N, Franklin RJ, Rowitch DH (2009) Dysregulation of the Wnt pathway inhibits timely myelination and remyelination in the mammalian CNS. Genes Dev 23:1571-1585.

Feigenson K, Reid M, See J, Crenshaw EB 3rd, Grinspan JB (2009) Wnt signaling is sufficient to perturb oligodendrocyte maturation. Mol Cell Neurosci 42:255-265.

Feigenson K, Reid M, See J, Crenshaw III EB, Grinspan JB (2011) Canonical Wnt signalling requires the BMP pathway to inhibit oligodendrocyte maturation. ASN Neuro 3:e00061.

Feng XH, Zhang Y, Wu RY, Derynck R (1998) The tumor suppressor Smad4/DPC4 and transcriptional adaptor CBP/p300 are coactivators for smad3 in TGF-beta-induced transcriptional activation. Genes Dev 12:2153-2163.

Fortin D, Rom E, Sun H, Yayon A, Bansal R (2005) Distinct fibroblast growth factor (FGF)/FGF receptor signaling pairs initiate diverse cellular responses in the oligodendrocyte lineage. J Neurosci 25:7470-7479.

Fuller ML, DeChant AK, Rothstein B, Caprariello A, Wang R, Hall AK, Miller RH (2007) Bone morphogenetic proteins promote gliosis in demyelinating spinal cord lesions. Ann Neurol 62:288-300.

Gaiano N, Nye JS, Fishell G (2000) Radial glial identity is promoted by Notch1 signaling in the murine forebrain. Neuron 26:395-404.

Gautier L, Cope L, Bolstad BM, Irizarry RA (2004) affy-analysis of Affymetrix GeneChip data at the probe level. Bioinformatics 20:307-315.

Gentleman RC, Carey VJ, Bates DM, Bolstad B, Dettling M, Dudoit S, Ellis B, Gautier L, Ge Y, Gentry J, Hornik K, Hothorn T, Huber W, Iacus S, Irizarry R, Leisch F, Li C, Maechler M, Rossini AJ, Sawitzki G, et al. (2004) Bioconductor: open software development for computational biology and bioinformatics. Genome Biol 5:R80.

Gomes WA, Mehler MF, Kessler JA (2003) Transgenic overexpression of Bmp4 increases astroglial and decreases oligodendroglial lineage commitment. Dev Biol 255:164-177.

Göttlicher M (2004) Valproic acid: an old drug newly discovered as inhibitor of histone deacetylases. Ann Hematol 83 [Suppl 1]:S91-S92.

Grinspan JB, Edell E, Carpio DF, Beesley JS, Lavy L, Pleasure D, Golden JA (2000) Stage-specific effects of bone morphogenetic proteins on the oligodendrocyte lineage. J Neurobiol 43:1-17.

Gross RE, Mehler MF, Mabie PC, Zang Z, Santschi L, Kessler JA (1996) Bone morphogenetic proteins promote astroglial lineage commitment by mammalian subventricular zone progenitor cells. Neuron 17:595-606.

Havrda MC, Johnson MJ, O'Neill CF, Liaw L (2006) A novel mechanism of transcriptional repression of p27kip1 through Notch/HRT2 signaling in vascular smooth muscle cells. Thromb Haemost 96:361-370.

Huang da W, Sherman BT, Lempicki RA (2009a) Bioinformatics enrichment tools: paths toward the comprehensive functional analysis of large gene lists. Nucleic Acids Res 37:1-13.

Huang da W, Sherman BT, Lempicki RA (2009b) Systematic and integrative analysis of large gene lists using DAVID bioinformatics resources. Nat Protoc 4:44-57.

Huang JK, Jarjour AA, Nait Oumesmar B, Kerninon C, Williams A, Krezel W, Kagechika H, Bauer J, Zhao C, Evercooren AB, Chambon P, FfrenchConstant C, Franklin RJ (2011) Retinoid X receptor gamma signaling accelerates CNS remyelination. Nat Neurosci 14:45-53.

Jablonska B, Aguirre A, Raymond M, Szabo G, Kitabatake Y, Sailor KA, Ming GL, Song H, Gallo V (2010) Chordin-induced lineage plasticity of adult SVZ neuroblasts after demyelination. Nat Neurosci 13:541-550.

Janknecht R, Wells NJ, Hunter T (1998) TGF-beta-stimulated cooperation 
of smad proteins with the coactivators CBP/p300. Genes Dev 12:2114-2119.

Kageyama R, Nakanishi S (1997) Helix-loop-helix factors in growth and differentiation of the vertebrate nervous system. Curr Opin Genet Dev 7:659-665.

Kim S, Kim SH, Kim H, Chung AY, Cha YI, Kim CH, Huh TL, Park HC (2008) Frizzled 8a function is required for oligodendrocyte development in the zebrafish spinal cord. Dev Dyn 237:3324-3331.

Kondo T (2009) [Common mechanism underlying oligodendrocyte development and oligodendrogliomagenesis]. Brain Nerve 61:741-751.

Lai EC (2004) Notch signaling: control of cell communication and cell fate. Development 131:965-973.

Liu A, Niswander LA (2005) Bone morphogenetic protein signalling and vertebrate nervous system development. Nat Rev Neurosci 6:945-954.

Liu A, Muggironi M, Marin-Husstege M, Casaccia-Bonnefil P (2003) Oligodendrocyte process outgrowth in vitro is modulated by epigenetic regulation of cytoskeletal severing proteins. Glia 44:264-274.

Liu A, Li J, Marin-Husstege M, Kageyama R, Fan Y, Gelinas C, CasacciaBonnefil P (2006) A molecular insight of Hes5-dependent inhibition of myelin gene expression: old partners and new players. EMBO J 25:4833-4842.

Liu J, Sandoval J, Doh ST, Cai L, López-Rodas G, Casaccia P (2010) Epigenetic modifiers are necessary but not sufficient for reprogramming nonmyelinating cells into myelin gene-expressing cells. PLoS One 5:e13023.

Manning L, Ohyama K, Saeger B, Hatano O, Wilson SA, Logan M, Placzek M (2006) Regional morphogenesis in the hypothalamus: a BMP-Tbx2 pathway coordinates fate and proliferation through Shh downregulation. Dev Cell 11:873-885.

Marin-Husstege M, Muggironi M, Liu A, Casaccia-Bonnefil P (2002) Histone deacetylase activity is necessary for oligodendrocyte lineage progression. J Neurosci 22:10333-10345.

Mason JL, Ye P, Suzuki K, D’Ercole AJ, Matsushima GK (2000) Insulin-like growth factor-1 inhibits mature oligodendrocyte apoptosis during primary demyelination. J Neurosci 20:5703-5708.

McCarthy KD, de Vellis J 1980 Preparation of separate astroglial and oligodendroglial cell cultures from rat cerebral tissue. J Cell Biol 85:890-902.

Mekki-Dauriac S, Agius E, Kan P, Cochard P (2002) Bone morphogenetic proteins negatively control oligodendrocyte precursor specification in the chick spinal cord. Development 129:5117-5130.

Menn B, Garcia-Verdugo JM, Yaschine C, Gonzalez-Perez O, Rowitch D, Alvarez-Buylla A (2006) Origin of oligodendrocytes in the subventricular zone of the adult brain. J Neurosci 26:7907-7918.

Miller RH, Dinsio K, Wang R, Geertman R, Maier CE, Hall AK (2004) Patterning of spinal cord oligodendrocyte development by dorsally derived Bmp4. J Neurosci Res 76:9-19.

Mori S, Leblond CP (1970) Electron microscopic identification of three classes of oligodendrocytes and a preliminary study of their proliferative activity in the corpus callosum of young rats. J Comp Neurol 139:1-28.

Nery S, Wichterle H, Fishell G (2001) Sonic hedgehog contributes to oligodendrocyte specification in the mammalian forebrain. Development 128:527-540.

Nohe A, Keating E, Knaus P, Petersen NO (2004) Signal transduction of bone morphogenetic protein receptors. Cell Signal 16:291-299.

Orentas DM, Hayes JE, Dyer KL, Miller RH (1999) Sonic hedgehog signaling is required during the appearance of spinal cord oligodendrocyte precursors. Development 126:2419-2429.

Peters A, Sethares C (2004) Oligodendrocytes, their progenitors and other neuroglial cells in the aging primate cerebral cortex. Cereb Cortex 14:995-1007.

Pombo PM, Barettino D, Ibarrola N, Vega S, Rodríguez-Peña A (1999) Stimulation of the myelin basic protein gene expression by 9-cis-retinoic acid and thyroid hormone: activation in the context of its native promoter. Brain Res Mol Brain Res 64:92-100.

Rios I, Alvarez-Rodríguez R, Martí E, Pons S (2004) Bmp2 antagonizes sonic hedgehog-mediated proliferation of cerebellar granule neurones through Smad5 signalling. Development 131:3159-3168.

Rivera R, Murre C (2001) The regulation and function of the Id proteins in lymphocyte development. Oncogene 20:8308-8316.

Sabo JK, Aumann TD, Merlo D, Kilpatrick TJ, Cate HS (2011) Remyelination is altered by bone morphogenic protein signaling in demyelinated lesions. J Neurosci 31:4504-4510.
Samanta J, Kessler JA (2004) Interactions between ID and OLIG proteins mediate the inhibitory effects of Bmp4 on oligodendroglial differentiation. Development 131:4131-4142.

See J, Zhang X, Eraydin N, Mun SB, Mamontov P, Golden JA, Grinspan JB (2004) Oligodendrocyte maturation is inhibited by bone morphogenetic protein. Mol Cell Neurosci 26:481-492.

Shen S, Li J, Casaccia-Bonnefil P (2005) Histone modifications affect timing of oligodendrocyte progenitor differentiation in the developing rat brain. J Cell Biol 169:577-589.

Shen S, Sandoval J, Swiss VA, Li J, Dupree J, Franklin RJ, Casaccia-Bonnefil P (2008) Age-dependent epigenetic control of differentiation inhibitors is critical for remyelination efficiency. Nat Neurosci 11:1024-1034.

Shimizu T, Kagawa T, Wada T, Muroyama Y, Takada S, Ikenaka K (2005) Wnt signaling controls the timing of oligodendrocyte development in the spinal cord. Dev Biol 282:397-410.

Sim FJ, Lang JK, Waldau B, Roy NS, Schwartz TE, Pilcher WH, Chandross KJ, Natesan S, Merrill JE, Goldman SA (2006) Complementary patterns of gene expression by human oligodendrocyte progenitors and their environment predict determinants of progenitor maintenance and differentiation. Ann Neurol [Erratum (2006) 59:990] 59:763-779.

Smyth GK (2004) Linear models and empirical bayes methods for assessing differential expression in microarray experiments. Stat Appl Genet Mol Biol 3:Article3.

Soula C, Danesin C, Kan P, Grob M, Poncet C, Cochard P (2001) Distinct sites of origin of oligodendrocytes and somatic motoneurons in the chick spinal cord: oligodendrocytes arise from Nkx2.2-expressing progenitors by a Shh-dependent mechanism. Development 128:1369-1379.

Suzuki T, Takeuchi J, Koshiba-Takeuchi K, Ogura T (2004) Tbx Genes Specify Posterior Digit Identity through Shh and BMP Signaling. Dev Cell 6:43-53.

Swiss VA, Nguyen T, Dugas J, Ibrahim A, Barres B, Androulakis IP, Casaccia P (2011) Identification of a gene regulatory network necessary for the initiation of oligodendrocyte differentiation. PLoS One 6:e18088.

Tekki-Kessaris N, Woodruff R, Hall AC, Gaffield W, Kimura S, Stiles CD, Rowitch DH, Richardson WD (2001) Hedgehog-dependent oligodendrocyte lineage specification in the telencephalon. Development 128:2545-2554.

Wada T, Kagawa T, Ivanova A, Zalc B, Shirasaki R, Murakami F, Iemura S, Ueno N, Ikenaka K (2000) Dorsal spinal cord inhibits oligodendrocyte development. Dev Biol 227:42-55.

Wang S, Sdrulla AD, diSibio G, Bush G, Nofziger D, Hicks C, Weinmaster G, Barres BA (1998) Notch receptor activation inhibits oligodendrocyte differentiation. Neuron 21:63-75.

Wang S, Sdrulla A, Johnson JE, Yokota Y, Barres BA (2001) A role for the helix-loop-helix protein Id 2 in the control of oligodendrocyte development. Neuron 29:603-614.

Wang Y, Cheng X, He Q, Zheng Y, Kim DH, Whittemore SR, Cao QL (2011) Astrocytes from the contused spinal cord inhibit oligodendrocyte differentiation of adult oligodendrocyte precursor cells by increasing the expression of bone morphogenetic proteins. J Neurosci 31:6053-6058.

Ye F, Chen Y, Hoang T, Montgomery RL, Zhao XH, Bu H, Hu T, Taketo MM, van Es JH, Clevers H, Hsieh J, Bassel-Duby R, Olson EN, Lu QR (2009) HDAC1 and HDAC2 regulate oligodendrocyte differentiation by disrupting the beta-catenin-TCF interaction. Nat Neurosci 12:829-838.

Yokota Y (2001) Id and development. Oncogene 20:8290-8298.

Yung SY, Gokhan S, Jurcsak J, Molero AE, Abrajano JJ, Mehler MF (2002) Differential modulation of BMP signaling promotes the elaboration of cerebral cortical GABAergic neurons or oligodendrocytes from a common sonic hedgehog-responsive ventral forebrain progenitor species. Proc Natl Acad Sci U S A 99:16273-16278.

Zhang Y, Argaw AT, Gurfein BT, Zameer A, Snyder BJ, Ge C, Lu QR, Rowitch DH, Raine CS, Brosnan CF, John GR (2009) Notch1 signaling plays a role in regulating precursor differentiation during CNS remyelination. Proc Natl Acad Sci U S A 106:19162-19167.

Zhang Y, Zhang J, Navrazhina K, Argaw AT, Zameer A, Gurfein BT, Brosnan CF, John GR (2010) TGFbetal induces Jagged 1 expression in astrocytes via ALK5 and Smad3 and regulates the balance between oligodendrocyte progenitor proliferation and differentiation. Glia 58:964-974.

Zhou YX, Armstrong RC (2007) Interaction of fibroblast growth factor 2 (FGF2) and notch signaling components in inhibition of oligodendrocyte progenitor (OP) differentiation. Neurosci Lett 421:27-32. 